\title{
TARİHİ BAĞLAMDA RUS TEKSTİLLERİ VE SANATÇI ANDREY MADEKİN
}

\author{
Özlem Erzurumlu JORAYEV*, Şebnem Ruhsar TEMIR GÖKÇELI'**
}

\section{Özet}

Peru'da, MÖ. 2500'lü yıllara ait olduğu saptanan dekoratif özellikler taşıyan dokumalar bulunmuştur. Çin'de, 10. ve 13. yüzyıllar arasında tekniği iyi bilen dokuma ustalarının olduğu ve tapestry dokumalara benzer dekoratif ipekli dokumalar yapıldığı bilinmektedir.

Rusya'ya bu teknik Avrupa'dan sonra gelmiş, ilk uygulama merkezi olan St. Petersburg duvar halısı fabrikası İmparatorluk tarafından 18. yüzyılın başlarında kurmuştur. Fabrikada, 18. yüzyılın sonlarında klasik konuların işlendiği tapestryler dokunurken, 19. yüzyılın başlarında İmparatorluk geleneklerini yansıtan dokumalar yapılmıştır. Tapestry dokumaları haricinde Rus tekstil tarihine bakıldığında, "Tapestry Şallar" olarak adlandırılan şal dokumalar ve ülke kimliğini yansıtan tekstil baskıcılığı ile öne çıktığı görülmektedir. Ayrıca, suzeni ve diğer nakışlar ile halı ve ikat uygulamalar bulunmaktadır.

Günümüzde Rusya'da, kendi üslubunu oluşturmuş sanatçıların eserlerine bakıldığında, klasik teknikle uygulanarak güçlü resimsel anlatımlara sahip duvar halıları kadar sanatçıların teknik ve uygulamada kendilerine özgü yorumlarıyla elde ettikleri serbest anlatımlarla da karşılaşılmaktadır. Çağımızda bulunan hızlı üretim ve tüketim algısı göz önünde bulundurulduğunda, uygulamaları oldukça zaman isteyen ve dokuması zahmetli olan klasik tapestry tekniği ile dokuma yapan sanatçılara özel bir saygı duyulmaktadır. Rusya özelinde bu sanatçllara örnek olarak verilebilecek önemli birçok isim, eserleri ile ulusal ve uluslararası sanat etkinliklerinde özel davetler almaktadır.

Bu sanatçlardan Andrey (Andrew) Madekin geleneğin izlerini taşıyan klasik ya da Rus sanat unsurlarını da barındıran modern ve özgün eserleri ile uluslararası sanatçılar arasında, çok yönlü yaklaşımları ile yerini almıştır. Madekin, Tapestry dokumaları ile ismini duyurmuş, birçok müze, özel koleksiyon, çeşitli sergi ve etkinliklerde eserleri ile kendini ve Rusya'yı temsil etmiştir. Ressam, yazar ve tasarımcı kimlikleri olan sanatçının eğitimci yönü de bulunmaktadır. Kuşkusuz, farklı disiplinlerde üretken olması tapestry dokumalarındaki başarısını da etkilemiş, birçok ülkede tanınmasını sağlamıştır. Bu makalenin konusu olarak

\footnotetext{
* Öğr. Gör., Marmara Üniversitesi, Güzel Sanatlar Fakültesi, Tekstil Bölümü, ORCID: 0000-0001-55187595, ozlem.erzurumlu@marmara.edu.tr, ozlemerzurumlu@gmail.com

** Prof. Dr., Uşak Üniversitesi, Güzel Sanatlar Fakültesi, Moda Tasarımı, ORCID: 0000-0001-8573-2566, sebnem.gokceli@usak.edu.tr
} 
seçilmesinde, çok yönlü bir sanatçı olması ve klasik tapestry tekniğini kendi üslubunu yansıtacak biçimde güçlü bir ifade aracı olarak kullanması önemli rol oynamıştır.

Anahtar kelimeler: Andrey Madekin, Tapestry, Dokuma Resim, Duvar Askısı, Rus Tekstilleri.

\title{
RUSSIAN TEXTILES IN HISTORICAL CONTEXT AND ARTIST ANDREY MADEKIN
}

\begin{abstract}
The oldest examples of artistic weavings were found in Peru at the beginning of the $2500 \mathrm{BC}$. It is known that there were weavers who knew the technique well between the 10th-13th centuries and that decorative silk weavings similar to tapestry weavings were made in China.
\end{abstract}

This weaving technique came to Russia after Europe, and the first application center, St. Petersburg tapestry factory established by the Empire in the early 18th century. In the factory, tapestries with classical subjects were woven in the late 18th century, while weaving reflecting the Imperial traditions was made in the early 19th century. When we look at the history of Russian textile except for tapestry weavings, it is seen that it stands out with its shawl weavings called "Tapestry Shawls" and textile printing reflecting the identity of the country. In addition, there are suzani and other embroidery, carpet and ikat applications.

Today, when we look at the works of artists who have created their own style, we encounter the free expressions of the artists with their own interpretations in technique and practice as well as the tapestries with strong pictorial expressions applied with classical technique in Russia. Considering the perception of rapid production and consumption in our age, a special respect is respected to the artists who weave with the classical tapestry technique, which takes a lot of time and is laborious to weave. Many important names, which can be given as examples to these artists in Russia, find a place in national and international art events with their works.

One of these artists, Andrey (Andrew) Madekin, has taken his place among international artists with his versatile approaches, with his classical works bearing the traces of tradition or his modern and original works that also include Russian art elements. Madekin made a name for himself with tapestry weavings and represented himself and Russia with his works in many museums, private collections, various exhibitions and events. The artist, who is a painter, writer and designer, also has an educator side. Undoubtedly, being productive in different disciplines has also affected his success in tapestry weaving, making him known with his artist identity in many countries. Being a versatile artist and using the classical tapestry technique as a powerful expression tool reflecting his style played an important role in the selection of artist as the subject of this article.

Keywords: Andrey Madekin, Tapestry, Weaving Picture, Wall Hanging, Russian Textiles. 


\section{Giriş}

Dokumacılık geçmişte ilk örneklerde doğada bulunan bitki ve meyve lifleri, kürk şeritleri ve hatta insan saçının yer aldığ 1 ilkel yöntemlerle uygulanmıştır. Uzun tekstil liflerinin elde edilmesi ve kullanımı ile gelişim göstermiştir. Tekstil, insanlığın gelişimi ile paralellik içinde olan, bulunduğu kültürün izlerini taşıyan, toplumların en önem verdiği unsurlardan biridir. Tekstil malzemesinin zamana karşı direnç gösterememesi nedeniyle günümüze çok az örnek ulaşabilmiştir. Bu örnekler, bulundukları toprakların tekstil geçmişi hakkında fikir vermesi bakımından tarihi önem taşımaktadır.

Kökleri eski Misır'a dayanan dokumacılıkta sanatsal uygulamalar olarak kabul edilen ilk örneklerden biri Kopt kumaşlardır. Bu kumaşların ortaya çıkışı Hristiyanlığın yayılması ile eş zamanlı olarak ortaya çıkmış ve bu dokumalarda dini konular işlenmiştir (Gazizova, 2015: 989). Eski Misır halkının dokuduğu Kopt örnekler, uygulandığı dönem ve toplum hakkında bilgiler sunan, belge niteliği taşıyan resimsel anlatıma sahip tarihi eserlerdir.

Duvar halısı olarak da adlandırılan ve kilim tekniği ile uygulanan tapestry dokumalarında detaylı resimleme yapabilmek için, renk kullanımının rolünü çok iyi kavramış olmak gerekmektedir. Ressamın paletinde belirlediği renk hızla sonuca ulaştırırken, tapestry dokumasında atkı ipliklerinin tek renk ya da karışım renklerde kullanımı ile uygulamada çok renklilik ve ara geçişler görsellikteki başarıyı sağlamaktadır. Kilim dokuma tekniği ile uygulanmış sanatsal dokumalar, İspanya'nın Doğu Müslüman kısmından Batı Avrupa'ya gitmiş, 12. ve 13. yüzyıllarda Alman dokumacı ustalar geliştirmiş ve 14. yüzyılın sonunda tüm Avrupa'ya yayılmıştır (Gazizova, 2015: 989). Tapestry dokumacılığı Rusya'da ise 1700'lü yılların başında uygulanmaya başlanmıştır.

\section{Rus Tekstilleri}

Rusya'nın Vetluzhsky-Vyatka bölgesinde, mezarlık alanda yapılan arkeolojik kazılarda, 9. ve 10. yüzyıllara ait kumaş kalıntıları bulunmuştur. Kumaşın Rusya'da dokunduğu ile ilgili net bilgi bulunmamaktadır. Süslemeleri olan siyah renkli yünlü bu kumaşın uygulamasında, kırık dimi örgü kullanılmıştır. Eğirme ve boyama işleminin yapılmış olması, kırık dimi örgü ile dokunması, dokumacılığın gelişim gösterdiğini kanitlamaktadır. Elde edilen tablet dokuma yünlü kurdele buluntularının ise Rusya'da dokunduğu kabul edilmektedir (Kochkurkina and Orfinskaya, 2016: 31).

Rusya'ya Kilim dokuma tekniği, Avrupa'dan daha sonra gelmiş, ilk uygulama merkezi olan St. Petersburg duvar halısı fabrikası İmparatorluk tarafından 18. yüzyılın başlarında kurulmuştur. 
Yüzyılın sonlarına doğru pamuklu üretim önem kazanmış ve sanayileşmede büyük katkı sağlamıştır. Doğu ile yapılan ticaret, sermaye ve deneyim kazanılmasına yol açmış ve 19. yüzyılın sonlarında, Avrupa'nın baskı teknolojisi ve tasarımlarında değişimin yolunu açmıştır. Arts\&Craft ve Art Nouveau hareketlerinin etkisi ile natüralist baskı desenleri ön plana çıkmıştır. Takip eden dönemlerde farklı akımların etkisi baskı tasarımlarına yansımış, baskı alanında soyut çalışmalar da gerçekleştirilmiştir (Yıldırım ve Sakalauskaite, 2011: 32).

Fransa'ya yaptığı seyahat sırasında kıymetli halıların dikkatini çekmesi üzerine I. Petro 1716 yılında Krallığın Goblen Fabrikasının dokumacıları ile St. Petersburg'da atölye kurulması ve çalışmaların düzenlenmesi konusunda, Paris'te 5 yıllık bir anlaşma imzalamıştır. 1717 yılında İmparatorluk, St. Petersburg duvar halısı fabrikasını kurmuş, yurtdışından malzeme ve boya getirilmiştir (Gazizova, 2015: 990). St. Petersburg fabrikasına 1730'lu yılların başlarında Rus dokumacılar alınarak geniş bir kadro oluşturulmuştur.

18. yüzyılın ikinci yarısı fabrikanın en verimli dönemi olmuştur. Fabrikada, 18. yüzyılın sonlarında klasik konuların işlendiği tapestryler dokunurken, 19. yüzyılın başlarında İmparatorluk geleneklerini yansıtan dokumalar yapılmıştır. Bu uygulamalar tarz olarak, devlet kurumlarında sergilenen dekoratif, büyük boyutlu tablolara benzemektedir. Sik görülen resimler, lüks İmparatorluk süslemeleri ile çerçevelenen, gündüz, gece, şafak alegorilerini barındırmaktadır. St. Petersburg fabrikasından sorumlu Bakanlar Kurulu, düşük kar ve yüksek masraf nedeniyle, 1828 yılında tapestry dokumalarının üretimini durdurmuş, sadece saraylarda kullanım için üretime devam edilmesi kararlaştırılmıştır. Fabrika 1 Haziran 1857 yılında II. Aleksandr tarafından kapatılmıştır (Korshunova, Hermitage Muzeum).

Tapestry dokumaları haricinde Rus tekstil tarihine bakıldığında, tapestry şallar olarak adlandırılan bu teknikle dokunmuş şallar ve ülke kimliğini yansıtan tekstil baskıcılığı ile öne çıktığı görülmektedir. Buna ek olarak, suzeni tekniğinde yapılmış işlemeler, nakışlar, halı ve ikat uygulamalar da bulunmaktadır.
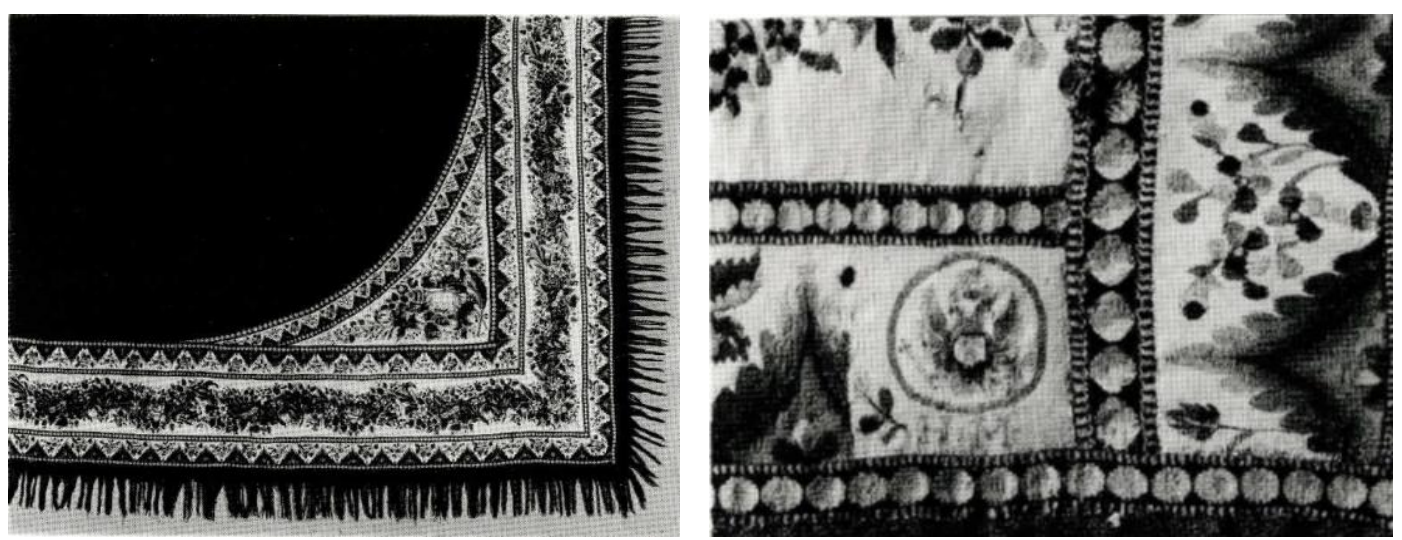

Görsel 1: Şal Detay1, Metropolitian Museum of Art. (Kaynak: Cooper, 1992: 236)

Görsel 2: Şal Detayı, Metropolitian Museum of Art. (Kaynak: Cooper, 1992: 236) 
1800 yılında kilim dokuma yapılması amaciyla Nadezhda Appolonovna Merlina'nın dokuma atölyesi kurulmuştur. Atölye 1806 yılında şal dokumacılığı yapmaya başlamıştır. Uygulamalarda kilim tekniği profesyonel olarak şal dokumacılığına uyarlanmış, çift yüzlü dokumalar gerçekleştirilmiştir. Çok ince kalitede dokunan bu şallarda 2/2 dimi örgü kullanılmıştır (Cooper, 1992: 225, 229). Kilim tekniği ile uygulanmış olmaları ve desen kapasitelerinden dolayı, sözü edilen Rus şal dokumaları goblen şallar ya da tapestry şallar olarak adlandırılmıştır.

Zengin toprak sahipleri ve soyluların sahip olduğu atölyelerde farklı kalitede dokunan "Rus El Dokuması Goblen Tekniği Şallar", 19. yüzyılın ortalarında endüstride pazar payı edinmiştir. Oldukça zahmetli üretimi olan tapestry şal dokumacılığı farklı atölyelerde yapılsa da Merlina'nın atölyesinde üretilen şallar kalitesi bakımından ön plana çıkmıştır (Wetenhall, 2010: 1).

1826 yılında devlet yönetimi, ulusal tarzın keşfini teşvik etmiş ve kararname yayınlamıştır. Bunun bir yansıması olarak şal üretiminde sarı, kırmızı, mavi gibi doygun renkler ve stilize edilmiş motifler kullanılmaya başlanmıştır. Bu şallar, Rus kimliğini yeniden oluşturan ve yansıtan örnekler olarak kabul edilmektedir (Wetenhall, 2010: 2, 5).

Rus kumaşları denilince; Büyük Katerina ve onu takip eden Romanov Hükümdarlığ1 dönemi gümüş ve altın teller kullanılarak dokunmuş ipekli tekstiller ya da Boris Godunov dönemi taşra köylülerinin giydiği kırmızı renkli başörtüler ve şallar akla gelmektedir. Bu kumaşların dışında, çok geniş bir coğrafyada yayılmış Rusya 'ya ait yaklaşık 1860- 1960 yılları arasında üretilen ve daha az bilinen ikat dokumalardan söz edilmektedir (Meller, 2007: 31).

Rus tekstillerinde ayrıca, zincir şeklinde uygulanan suzeni (işlemeli duvar askısı) adı verilen işlemeler bulunmaktadır. Suzeni ve diğer nakışların sadece evlerde uygulandığ1 düşünülürken, 1870 yılına ait Moskova sergi kataloğunda bulunan bir açılama, işlemelerin yapıldığı erkek loncaların varlığından bahsetmektedir.

Halı konusuna bakıldığında ise uluslararası alana ve Sovyet pazarına dokunan Türkmen halıları ile Özbek, Kırgız ve Kazakların evde kullanmaları için dokunan tüylü halıların üretiminden söz edilmektedir. Devrim sonrası Sovyet halılarında, geleneksel geometrik düzenlemeler ve çiçekli bordür desenleri devamlılığını korurken, kahramanlıkları anlatan konu ve figürlerin ele alındığı, Avrupa tarzı tabloları ve kişisel portrelerin alanla bütünleştirildiği ürünler bulunmaktadır (Fitz- Gibbon, 2004: 125).

İngiltere'nin devlet destekli endüstriyel sanat müfredatı örnek alınarak, 1860 yılında Moskova'da "Imperial Central Stroganov School of Technical Design" kurulmuştur. Okulun kurulum amacı, Rus ürünlerinin sanatsal ve karakteristik özelliklerini uluslararası platformda tanıtmaktır. Rusya'nın Ivanovo şehrinde 
üretilen tekstillerin tasarımcıları, genellikle bu okulda eğitim almışlardır (Meller, 2007: 32).

20. yüzyıl başlarında üretilen dönemin canlı renklerdeki tekstil tasarımları, 1917 yılında gerçekleşen Ekim Devrimi ile yapılanan yeni toplumun tarzını yansıtarak, yeni kumaş tasarımları yaratma çabasının ürünü ve hükümetin bu konudaki kararlı politikasının bir sonucudur. 1920'lerin sonlarında endüstri için sanatçı ve tasarımcı yetiştirmek amacı ile Moskova'da Vkhutemas (Vysshie Gosudarstvennye Khudozhestvennotekhnicheskie Masterskie) adlı sanat okulu kurulmuştur. Sovyet Bauhaus'u olarak söz edilen okulda dönemine göre birçok yenilikçi yaklaşım geliştirilmiştir (Lodder, 2018: 139-140).

Vkhutemas okulunda eğitim alan öğrencilere öncelikle, renk, biçim, malzeme, hacim ve mekân manipülasyonu konusunda temel deneyimler kazandırılmıştır. Ön eğitim sonrasında öğrenciler, ilgili fakültelerden birinde eğitim almaya başlamıştır. Okulun Tekstil Fakültesi, devrim öncesi kurulmuş olan Stroganov Okulu'nun dokuma, baskı ve sanatsal dikiş atölyelerinin olanakları içinde yeniden oluşturulmuştur. Endüstri ile yakın ilişkisi olan fakültenin amacı, yetenekli teknolojik uzman yetiştirmektir (Lodder, 2018: 144-145).

Sanatsal tekstillerle ilgili dersler, tekstil tasarımı ve üretiminin endüstriyel yönleri ve nasıl ilişkilendirileceği ile paralel olarak yürütülmüştür. Dokuma Bölümünde, kompozisyon dersi deneyimli M. Tikhomirnov tarafından verilmiş, tasarımın kusursuz bir ürüne dönüşme süreci vurgulanmıştır. Vkhutemas okulu, 1929-1930 akademik yılının sonunda kapatılmış, mezunlar endüstride çalışmaya devam etmişlerdir. Okulda, özellikle Tekstil Fakültesi, hem estetik hem de teknik anlamda donanımlı, endüstride çalışacak profesyonel tasarımcılar yetiştirilmiştir (Lodder, 2018: 148-149,157).

Sovyetler döneminde tekstil endüstrisinin ilerleyiş politikası, halkın fonksiyonel ve estetik ürünlere sahip olmasını destekler yöndedir. Sovyetler Birliği ideolojisinin dinamiklerinin tekstil tasarımlarına yansıdı̆̆ı bu dönemde, konstrüktivizm etkisi olan asimetrinin, fotomontaj ve geometrik formların öne çıktığı, ritim, hareket olgularını barındıran, elektrik, ışık ve ses elemanlarının işlendiği tasarımlar gerçekleştirilmiştir (Yıldırım ve Sakalauskaite, 2011: 32-33). 

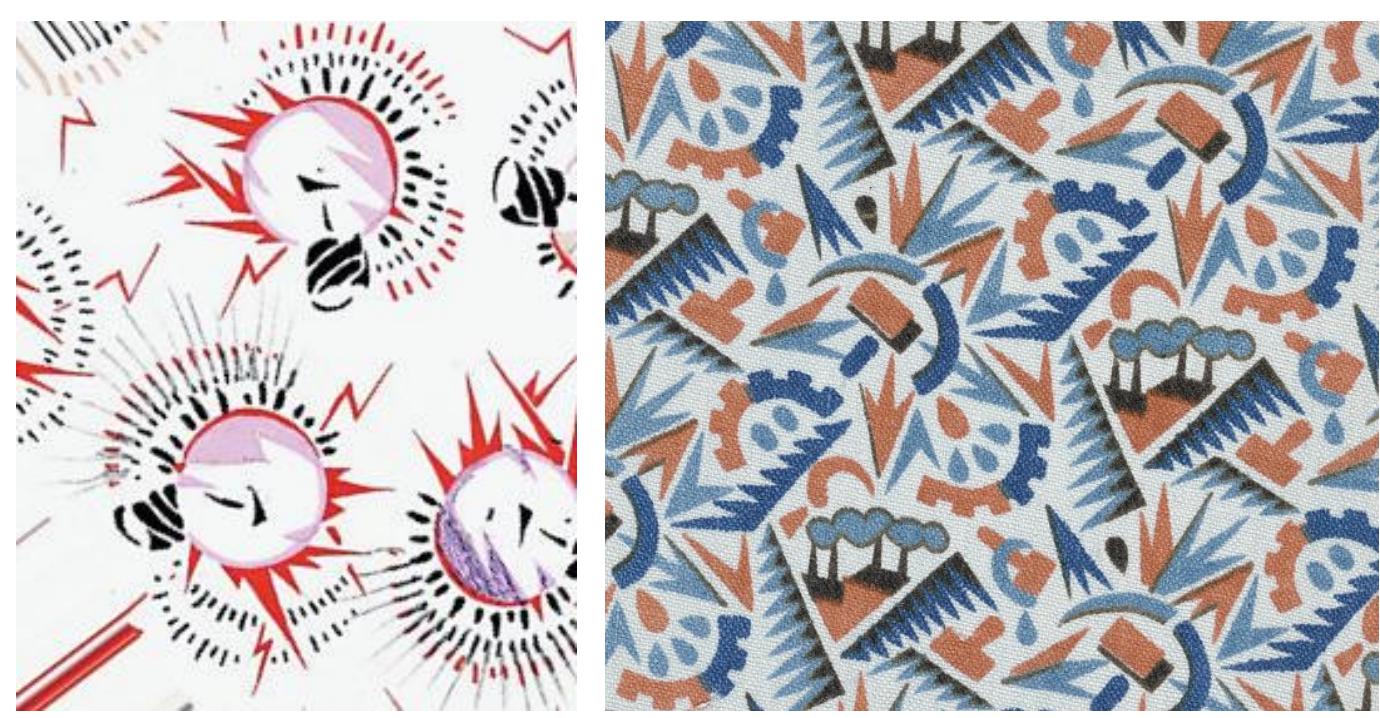

Görsel 3: “Elektrik Ampulleri”, Oskar Griun, Baskılı Kumaş, 1920’ler. (Kaynak: Lodder, 2018: 149) Görsel 4: “Endüstri”, Daria Preobrazhenskaia, Bask1lı Kumaş, 1927-1930. (Kaynak: Lodder, 2018: 149)

Tekstilde, bu ideoloji doğrultusunda gelişen yeni yapılanma, Batı tasarımları yerine toplumun ihtiyaçları gözetilerek, emeğe dayalı tasarım ve üretim olarak ortaya çıkmaktadır. Sovyetler Birliğinin ilk yıllarında Konstrüktivist yaklaşımların haricinde fabrika ve ulaşım konularının vurgulandı ̆̆ı, uçak, traktör, buğday başağı, orak, çekiç, gibi unsurları barındıran tasarımlar da gerçekleştirilmiştir.

Çağdaş sanatçıların çalışmalarına bakarak, günümüzde Sovyetler Birliği'nin çöküşünden önce yapılanlara kıyasla çok büyük bir gelişme ve değişim olmadığı söylenebilir. 1990 yıllarda sanatçılar üzerindeki ideolojik baskı kalkmış, kişiselleştirilmiş sanatın önünde duran, basmakalıp temalar, dini konular da dâhil olmak üzere tüm yasaklar neredeyse geçmişte kalmıştır (Dvorkina, 2018: 195).

Bugün Rusya'da Sovyetler birliği zamanında üretilenden daha fazla orijinal eser, duvar halısı çeşitleri bulunmakta, anıtsal mekânlar için üretilmiş tapestrylerden küçük mekânlara uygun tasarımlara ve mini duvar halılarına kadar çeşitli eserler mevcuttur. Kendi üslubunu oluşturmuş Rus sanatçllar, özel istisnalar dışında bugün genellikle figüratif duvar halısı olarak kabul edilebilecek gerçekçi bir anlatımın klasik çizgisini sürdürmektedir (Dvorkina, 2018: 195).

Günümüzde çoğu sanatçı, duvar halılarını kendi eskizlerine göre, titizlikle ve çok iyi bir kalitede dokumaktadır. Malzeme konusunda çok renkli ve çeşitli kalitelerde ipliklere ulaşabilmektedir. Renkler daha parlak hale gelmiş ve kompozisyonlar daha özgür koşullarda üretilmeye başlanmıştır. Ancak dokuma tekniği kendi özel alanında, az sayıda deneysel örnekler bulunsa da neredeyse hiç bir değişikliğe uğramamıştır.

Tapestry dokuyan bir sanatçı için halka açık bir iç mekânı dekore etmek son derece değerlidir. Elbette Sovyet dönemine göre bu tür eserlere olan talebin sayısı çok azalmıştır. Sanatçı için siparişi karşılamak üzere eser üretmek yerine, sanatsal değerinin önemi açısından sergi çalışmalarını gerçekleştirmek daha fazla ilgi 
çekmekte ve tercih edilmektedir. Bu bağlamda sanatçı müşterisinin taleplerini ve beklentilerini karşılamak zorunda olmadan yarattığından, genellikle sanat düzeyi yüksek, deneysel çalışmalar ortaya çıkmaktadır. Sanatçıların genel isteği ise sergiler sona erdiğinde bu duvar halılarını, depolara kaldırmak yerine müzelerde ya da daimi sergileme alanlarında halkla buluşturmaktır.

2011 ve 2014 yıllarında Moskova Tsaritsyno Müze alanında düzenlenen Tapestry Trienallerinden sonra Rusya'da duvar halılarına olan ilgi de özel bir artış izlenmiştir. Baltık Devletleri, Ukrayna, Beyaz Rusya, Moldova, Kazakistan gibi eski Sovyetler Birliği Cumhuriyetlerinin bazıları bu trienallere sanatçılarıyla katılmıştır. Sanatçıların bir grubu klasik tapestry tekniğinde üretmeye devam ederken, diğerleri çeşitli yeni trendlerin etkisiyle ürettikleri eserlerle bu etkinliklerde katılımcı olarak yer almışlardır (Dvorkina, 2018: 195-196). Günümüzde tapestry çalışmaları yapan Rus sanatçllara örnek olarak, Olga Popova, İina Smagina, Yelena Nefodova, Lyudmila Kramar, Vladimir Muhin, Olga Oreşko, Olga Gluhova ve yapılan bu çalışmaya konu olan çok yönlü sanatçı Andrey Ilyich Madekin'den söz edebiliriz.
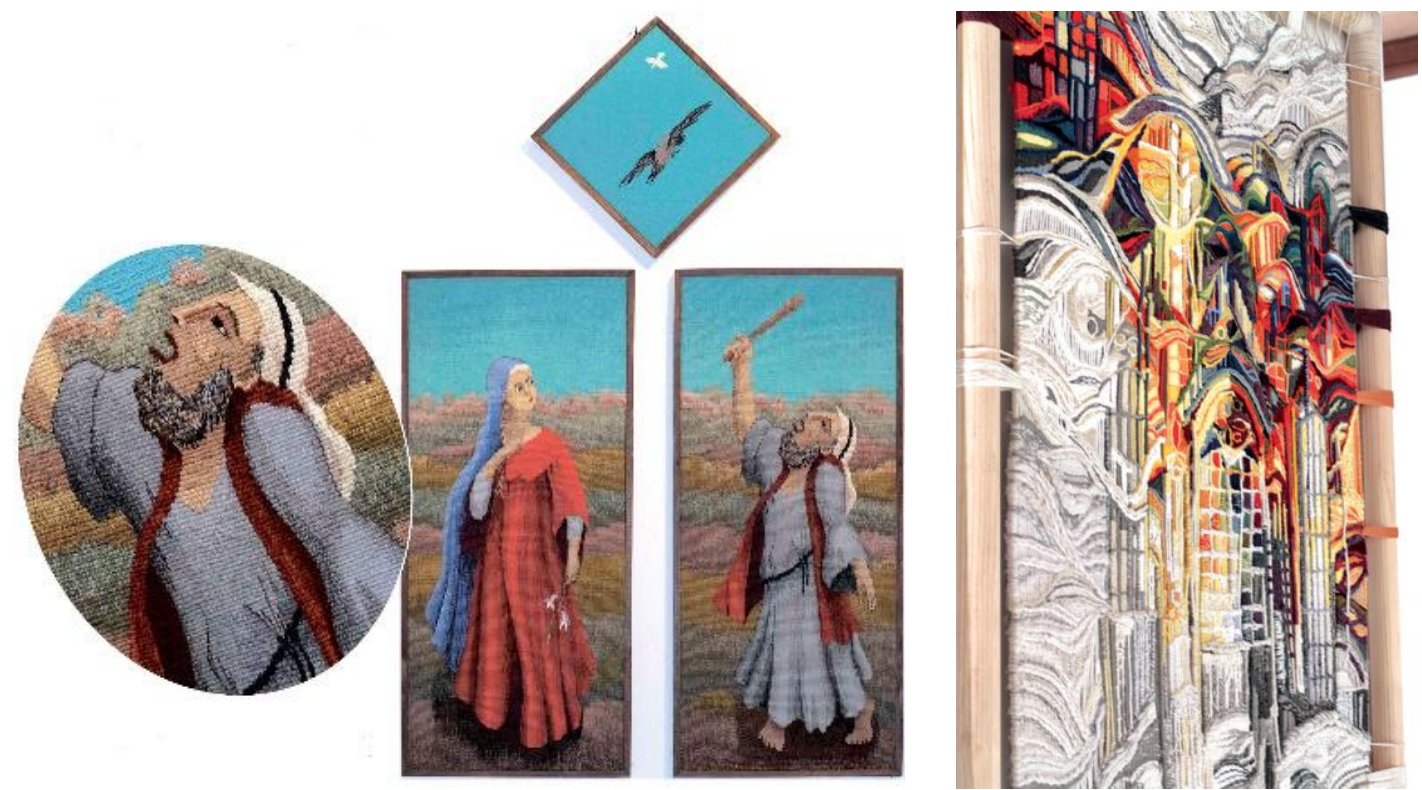

Görsel 5: “Pederin Önüne Geçme”, Lyudmila Kramar, 1948. (Kaynak: Dvorkina, 2018: 202)

Görsel 6: “Kale. Donmuş Pencereden”, Olga Gluhova, 130x80cm, 1989. (Kaynak: Dvorkina, 2018: 204) 

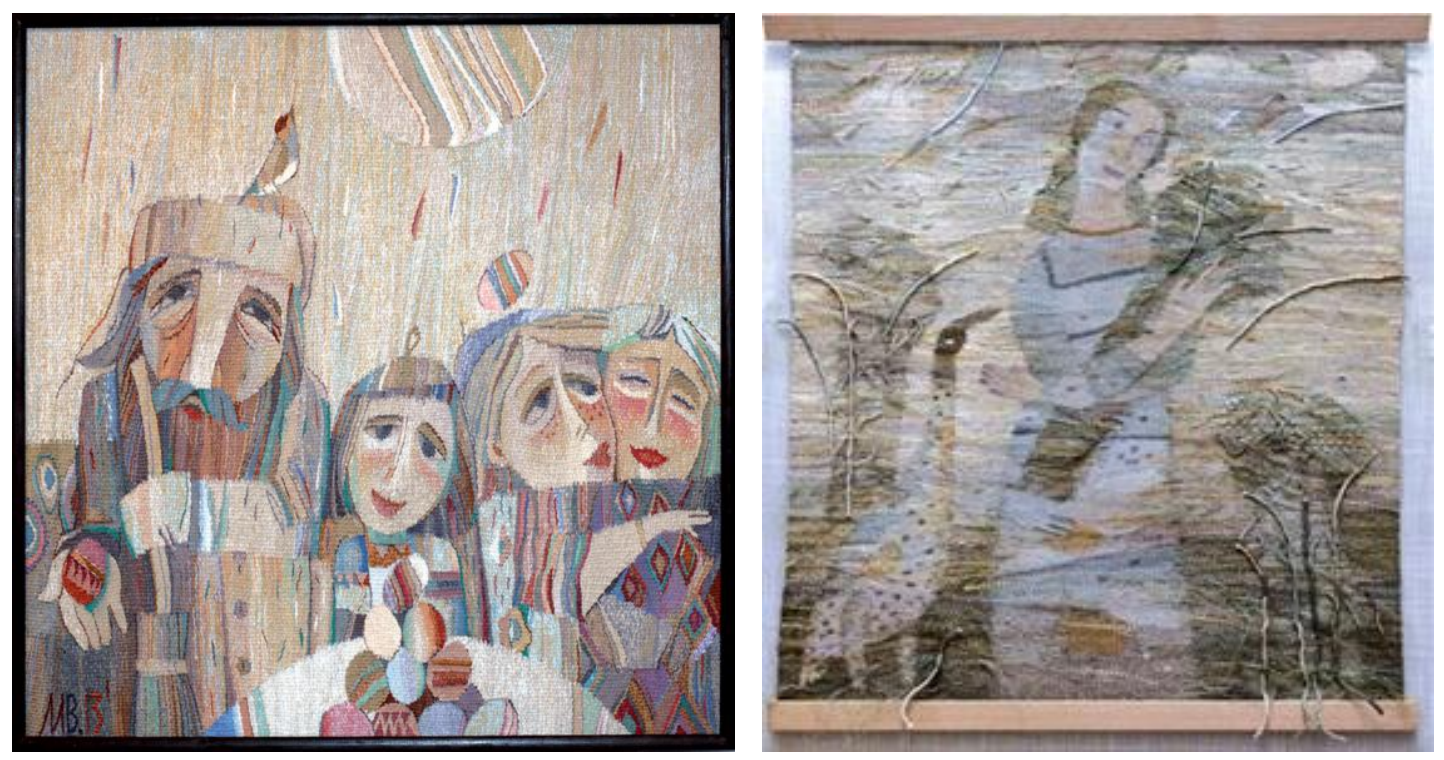

Görsel 7: “Çocukluğumdaki Parlak Pazar Günü", Vladimir Muhin, 90x90cm, 1948. (Kaynak: Dvorkina, 2018: 203)

Görsel 8: “Keten”, Olga Oreshko, 105x95cm, 2011. (Kaynak: Dvorkina, 2018: 204)

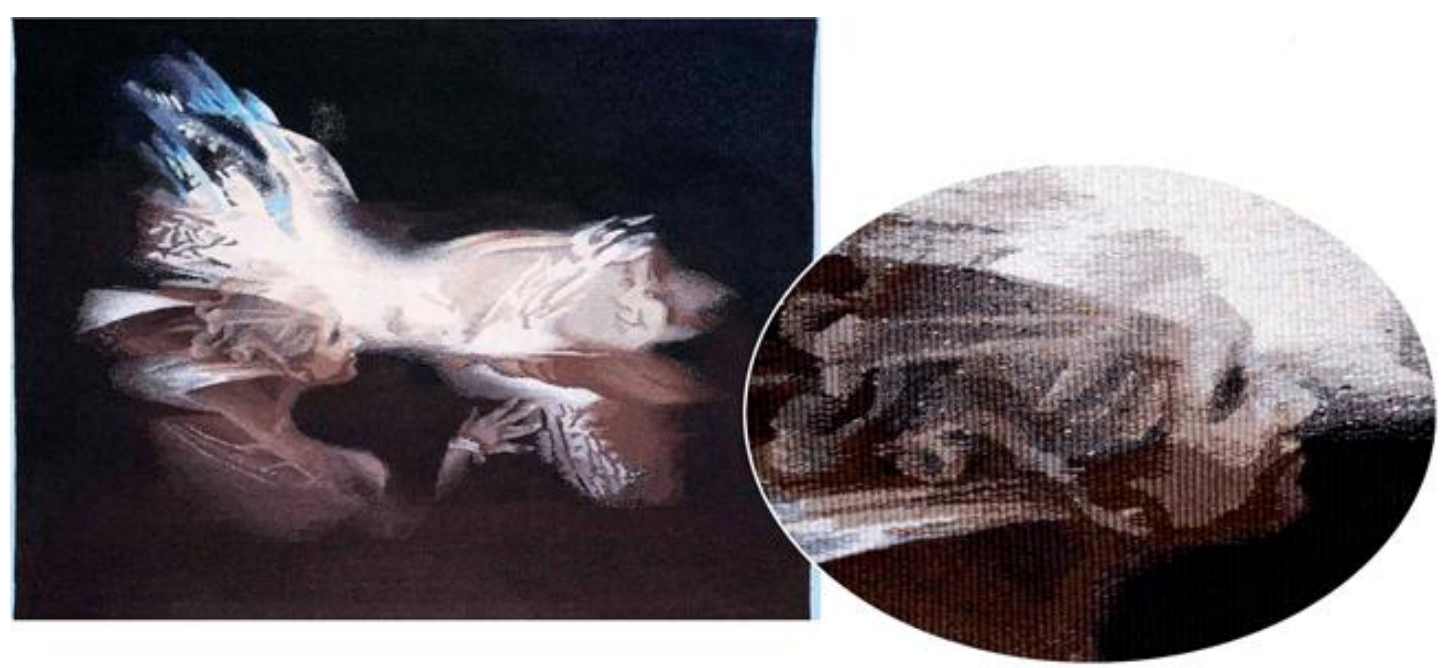

Görsel 9: Nesil Koleksiyonundan "Parti" İsimli Eser, İrina Smagina, 130x160cm. 2010. (Kaynak: Dvorkina, 2018: 201) 

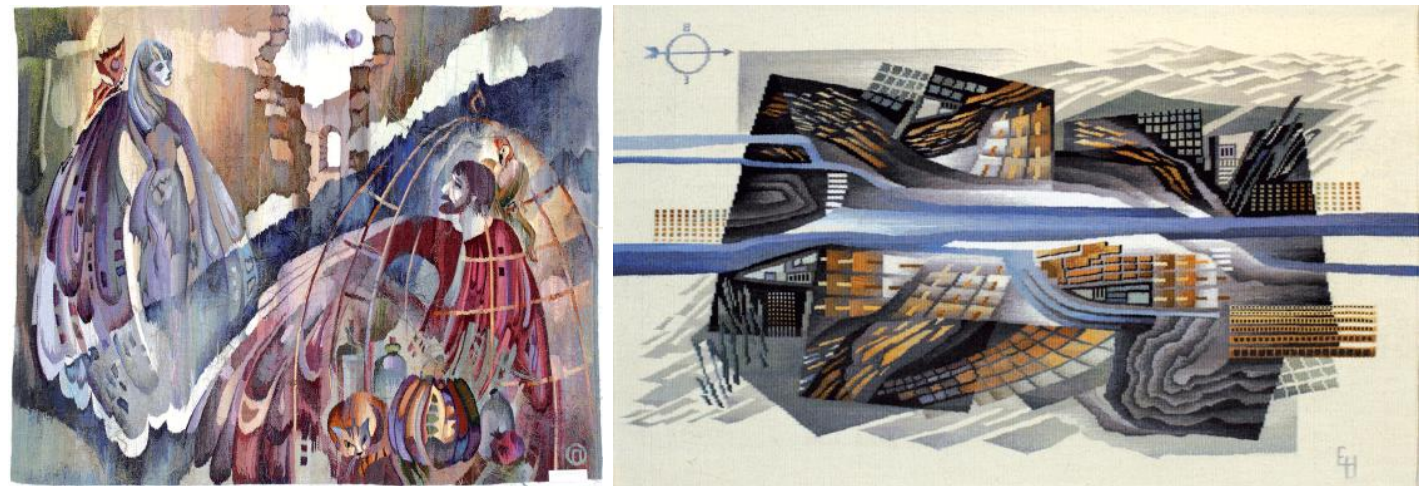

Görsel 10: “Belki, Fikrini Değiştirirsin?...”, Olga Popova, 135x175cm. (Kaynak: Dvorkina, 2018: 199.)

Görsel 11: “Nehir. Şehir”, Yelena Nefedova, 130x160cm. (Kaynak: Dvorkina, 2018: 201)

\section{Andrey Ilyich Madekin}

Andrey (Andrew) Ilyich Madekin (Андрей Ильич Мадекин), 1963 yılında Moskova'da doğmuştur. Tekstille ayrılmaz bağları bulunduğunu vurgulayan sanatçı, anne tarafından dedelerinin 19. yüzyıl öncesi Rusya'nın tekstil konusunda çalışan ve önde gelen işadamları arasında olduğunu belirtmiştir. Babasının büyükbabası Pavel Nikanorovich Derbenev'in (Görsel 12) 1894'ten 1905'e kadar Ivanovo-Voznesensk şehrinin Belediye Başkanlığının yanı sıra tekstil alanında çalışan bir iş adamı olduğunu ifade etmiştir (Madekin, 2020b).
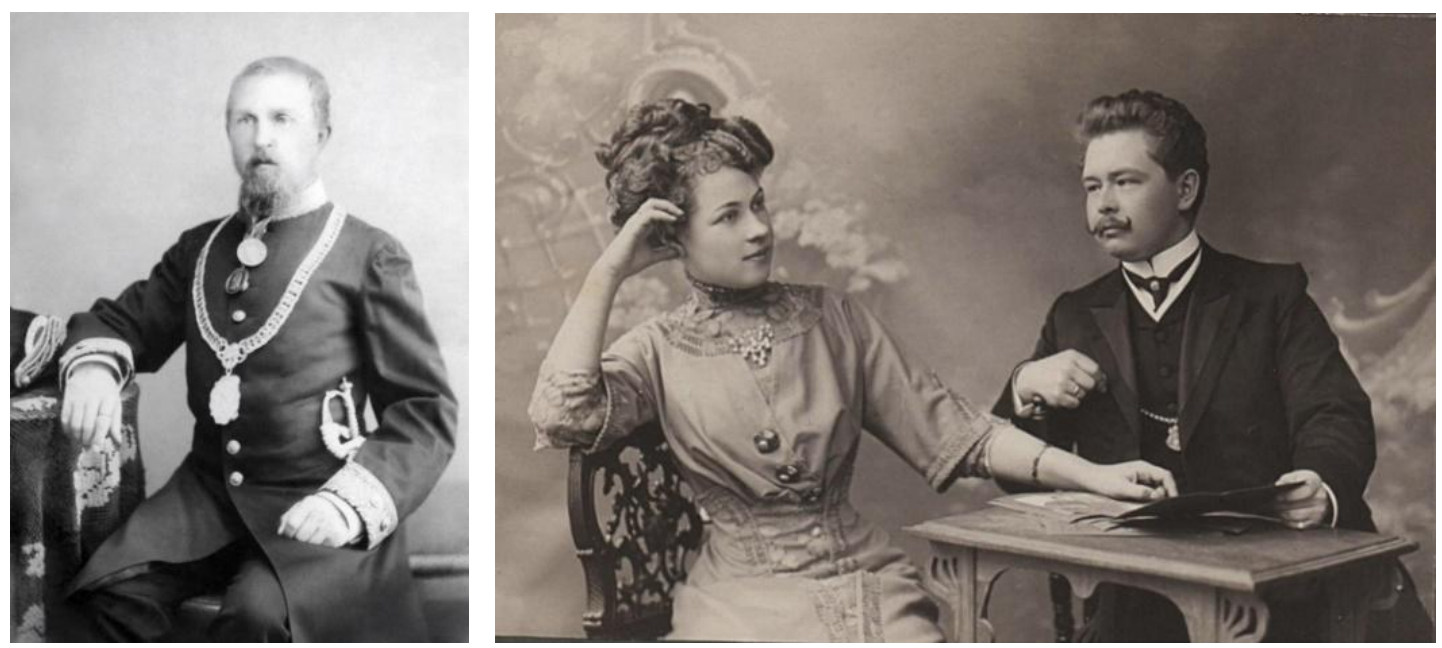

Görsel 12: Andrey Madekin'in büyük dedesi, tekstil konusunda çalışan iş adamı Pavel Nikanorovich Derbenev, 1990. (Kaynak: Sanatçının kişisel arşivinden)

Görsel 13: Andrey Madekin'in büyükannesi ve büyükbabasının düğün fotoğrafı, 1909. (Kaynak: Sanatçının kişisel arşivinden) 

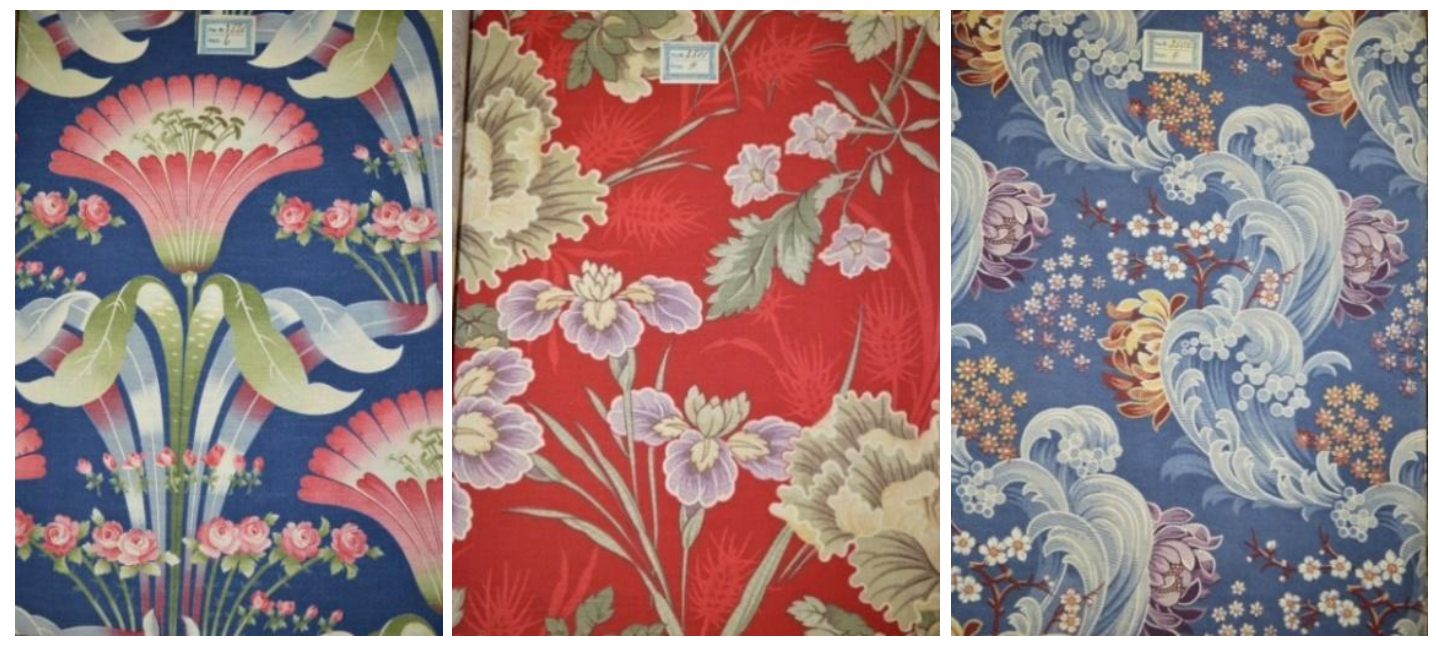

Görsel 14: Andrey Madekin'in büyük dedesinin fabrikalarında uygulanan baskı desenleri. (Kaynak: Sanatçının kişisel arşivinden, 1910)

Sekiz nesil tekstille ilgili olan ailede Madekin, günümüzde bu konu ile ilgilenen tek aile ferdidir. Atalarının, Rus devriminden önce tekstil baskıcılığ yaptıklarını belirtmiştir (Madekin, 2020a). Sanatçı, genetik hafızası ve yaratıcılığının mesleğini seçme konusunda rol oynamış olabileceğini ifade etmiştir (Madekin, 2020b).

Andrey 1985 y1lında, Moskova Teknoloji Enstitüsü Uygulamalı Sanatlar Fakültesi'nden mezun olmuştur. Tekstil eğitimi alan sanatçı, 20 yaşında öğrenciyken (1983) dokuma yapmaya başlamıştır. İlk bağımsız çalışmaları ile uzmanların dikkatini üzerine çekmiştir. 1988 yılında Rusya Sanatçılar Birliği'ne kabul edilmiş, 1990 yılında da Moskova Sanatçlar Birliği'ne üye olmuştur (Madekin, 2020b). 1987 yılında ilk büyük tapestry eserini uygulayan sanatçı, o zamandan itibaren yılda ikiüç adet tapestry dokuduğunu belirtmiştir. Günümüze kadar doksan civarında tapestry dokuyan sanatçı, yaklaşık elli eserinde boyutların 3 ila 6 metrekare arasında değiştiğini vurgulamıştır (Madekin, 2020a). 


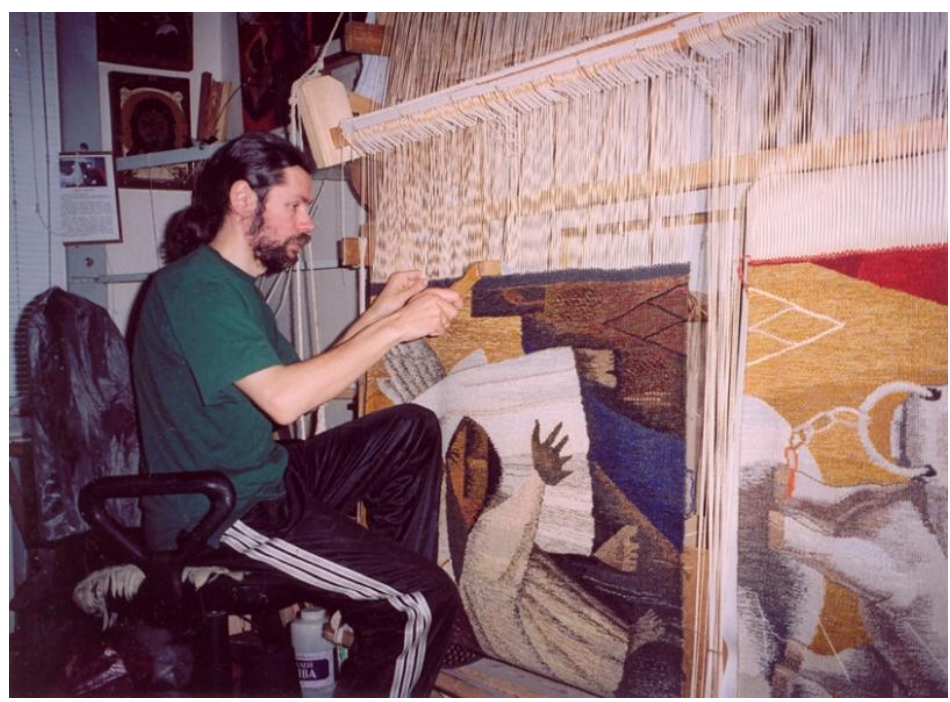

Görsel 15: Andrey Madekin, Atölyesinde kilim tezgâhında çalıştığı anlardan biri. (Kaynak: Sanatçının kişisel arşivinden, 2003)

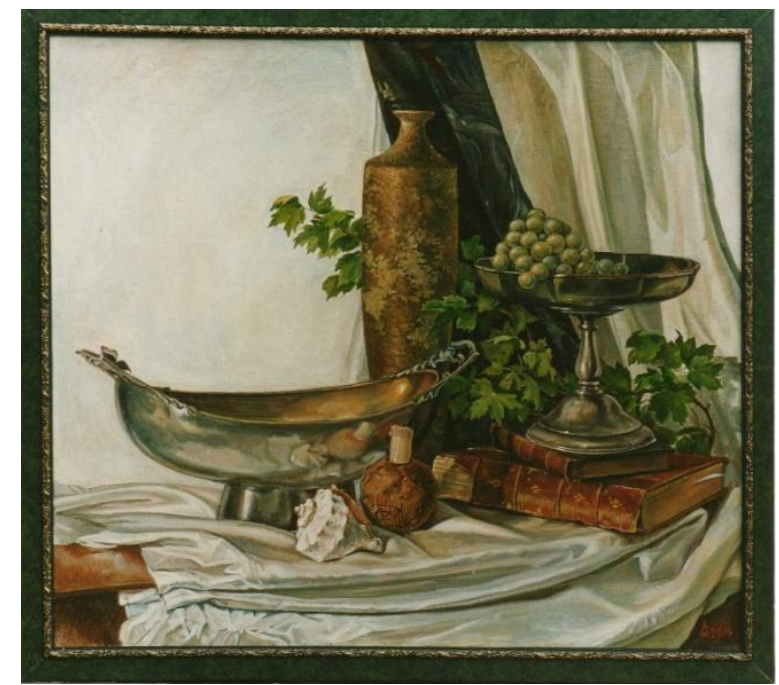

Görsel 16: “Gümüşlü Natürmort”, Andrey Madekin, 80x90cm, 2001. (Kaynak: Sanatçının kişisel arşivinden)

Madekin, özel tasarım ürünü olan halıların tasarlanması, özellikle tapestry dokumacılığı ve resim alanlarında çalışmaktadır. Pek çok portre, natürmort ve manzara resmi çizmiştir. 2003 yılından itibaren Amerikan (Philadelphia) firması Carpets Design Company'nin Moskova ofisinde baş ressam olarak çalışmaktadır. Yıllar süren işbirliği içinde, bu firma için Fas ve Nepal'de dokuması yapılan birkaç düzine proje ve ilgili tasarımlar gerçekleştirilmiştir (Madekin, 2020b). Moskova'da küçük bir enstitüde, halen resim ve sanat üzerine eğitim verdiğini belirten Madekin, geçmişte dokuma üzerine kısa süreli bir eğitimcilik deneyimi yaşadığını da ifade etmiştir (Madekin, 2020a). 


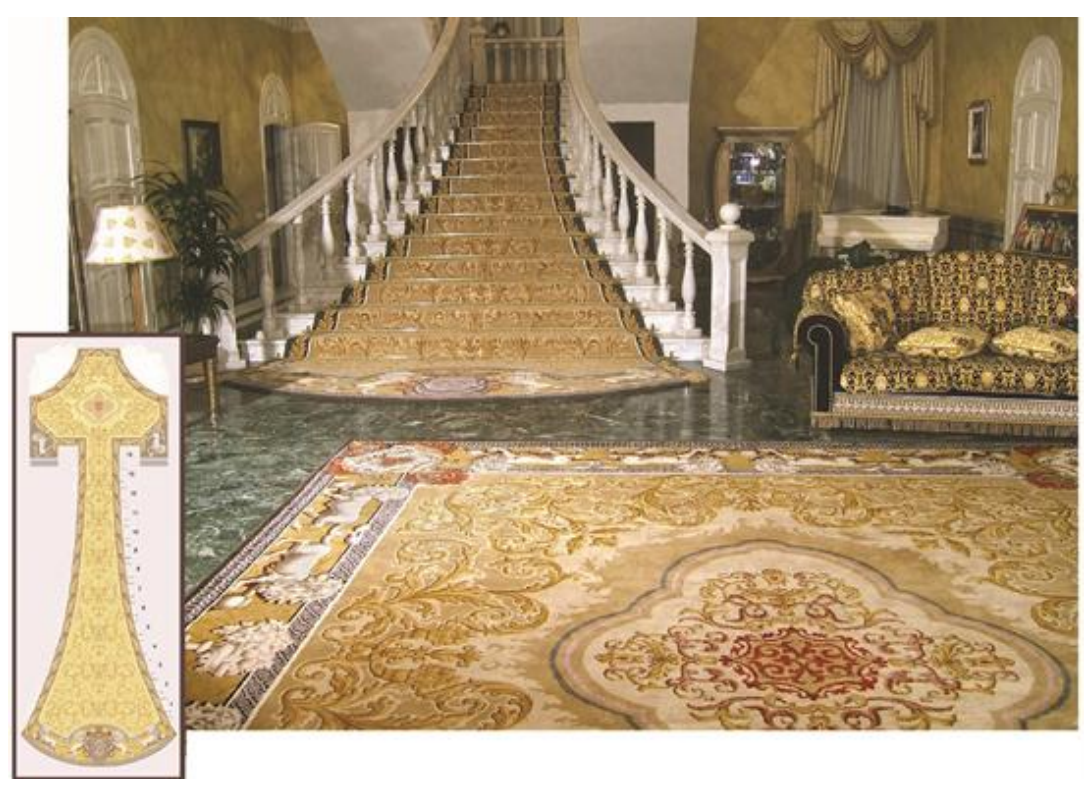

Görsel 17: "Aslanlar", Tasarımı Andrey Madekin'e ait hall, 520x450cm, 2005. (Kaynak: Sanatçının kişisel arşivinden)

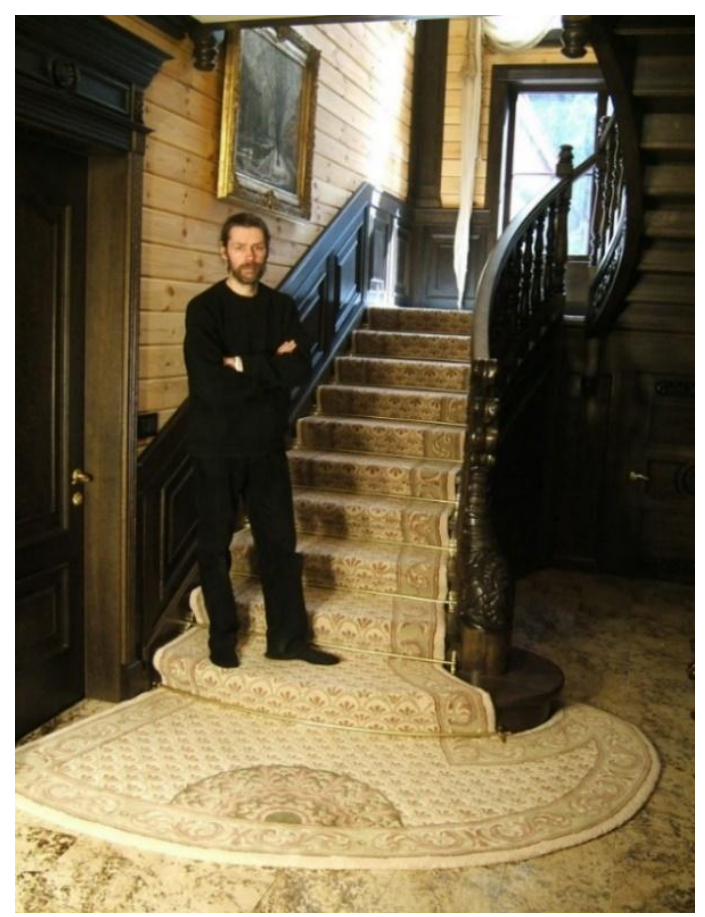

Görsel 18: Tasarımı Andrey Madekin'e ait "Rus" tarzında dokunmuş halı, 600x1000cm, 2006. (Kaynak: Sanatçının kişisel arşivinden) 

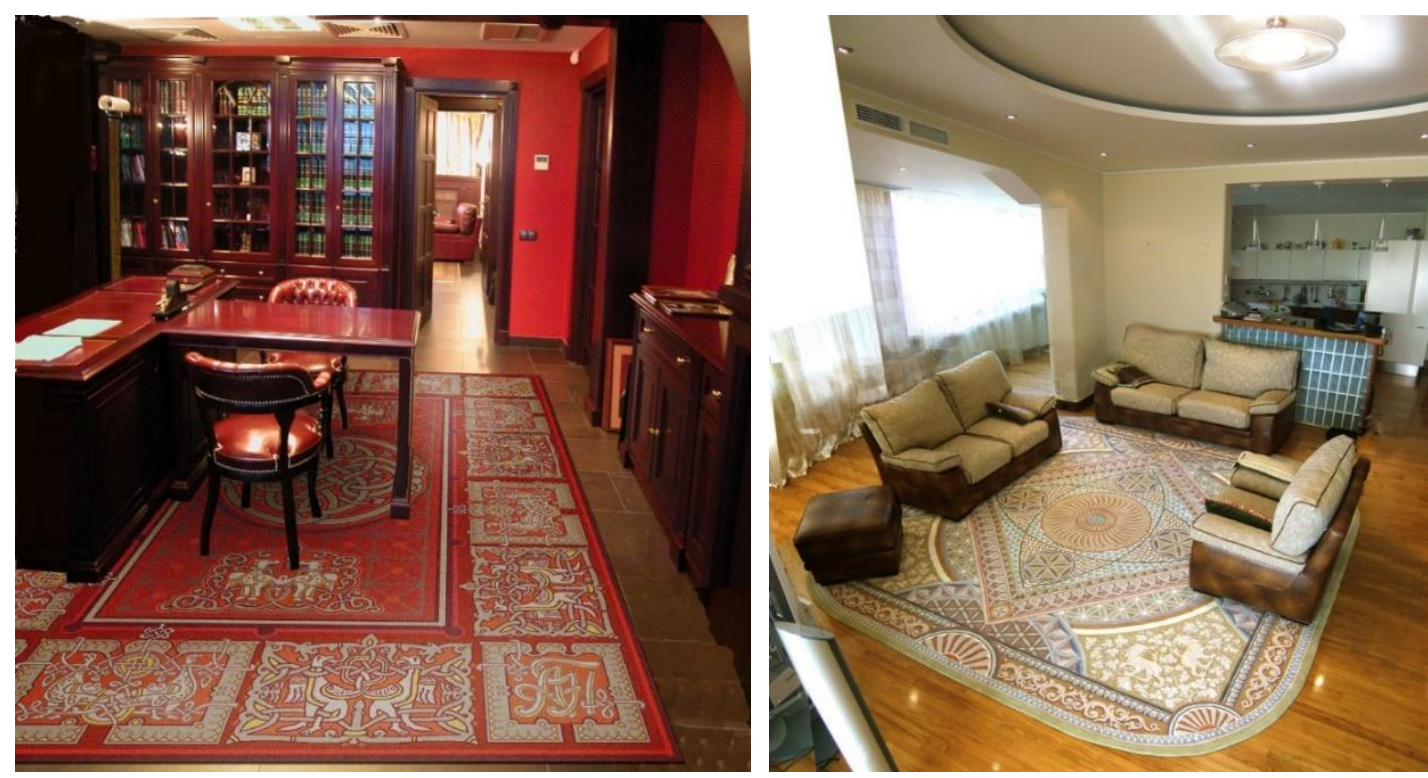

Görsel 19: Tasarımı Andrey Madekin'e ait "Kelt” tarzında dokunmuş halı, 400x250cm, 2009. (Kaynak: Sanatçının kişisel arşivinden)

Görsel 20: Tasarımı Andrey Madekin'e ait "Rus Halk Sanatı" tarzında dokunmuş halı, 400x400cm, 2007. (Kaynak: Sanatçının kişisel arşivinden)

Andrey Madekin son on yıldır edebiyat alanıyla da ilgilenmektedir. Ana ilgi alanı sanat tarihi olup, sanat tarihi ve teorisi üzerine çalışmaktadır. Bu alandaki görüşlerini birkaç kitap ve makalede özetlemiştir. "Sanat ve Cazibe", "Maximilian Voloshin'in Gizemi veya Sanat Nedir?" ve "Kiyametin Yorumu" adlı edebiyat alanında yazılmış eserleri de bulunmaktadır (Madekin, 2020b).

Madekin birçok ülkede kişisel-karma sergiler açmış, eserleri ile bienallere ve trianellere katılmıştır. Eserleri, Rusya Federasyonu Kültür Bakanlığı, Rusya Federasyonu Dışişleri Bakanlığı, Moskova Tsaritsyno Saray Müzesi, Rusya Devlet Sosyal Üniversitesi (RSSU), Rusya Ivanovo Bölgesel Sanat Müzesi, Tüm Rusya Dekoratif, Uygulamalı ve Halk Sanatları Müzesi (VMDPiNI), Rusya'nın Kore Demokratik Cumhuriyeti Seul Büyükelçiliği ikametgâhı, Polonya Lodz şehrindeki Centralne Muzeum Wlokiennictwa (Central Museum of Textiles) ve Sejny şehrindeki Pogranichye Vakfı, Amsterdam'da Jona Stichting Vakfı koleksiyonlarında yer almaktadır. Ayrıca Rusya ve diğer ülkelerde birçok özel koleksiyonda eserleri bulunmaktadır. Amsterdam'da, Ferrara'da Palazzo della Racchetta'da ve ayrıca Rusya ve diğer ülkelerin birçok özel sanat dergilerinde eserleriyle yer almıştır. Sanatçı, Rusya Sanat Akademisi Gümüş Madalyası ve Onur Diploması (2005), Rusya Sanatçılar Birliği Fahri Diplomaları (2005, 2011), Moskova Sanatçılar Birliği Onur Madalyası (2010), Dekoratif Sanatlar Sanatçıları Derneği Onur Madalyası (2013) almış ve Rusya Federasyonu Kültür Bakanından Takdir Yazısı (2016) ile ödüllendirilmiştir. 


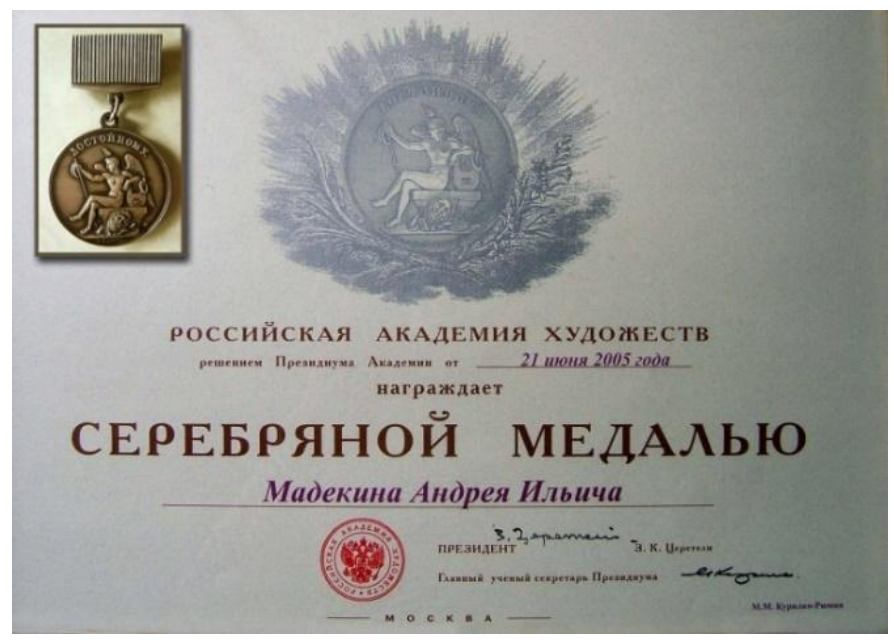

Görsel 21: Rusya Sanat Akademisi tarafından Andrey Madekin'e verilen, Gümüş Madalya ve ödül sertifikası, 2005. (Kaynak: Sanatçının kişisel arşivinden)

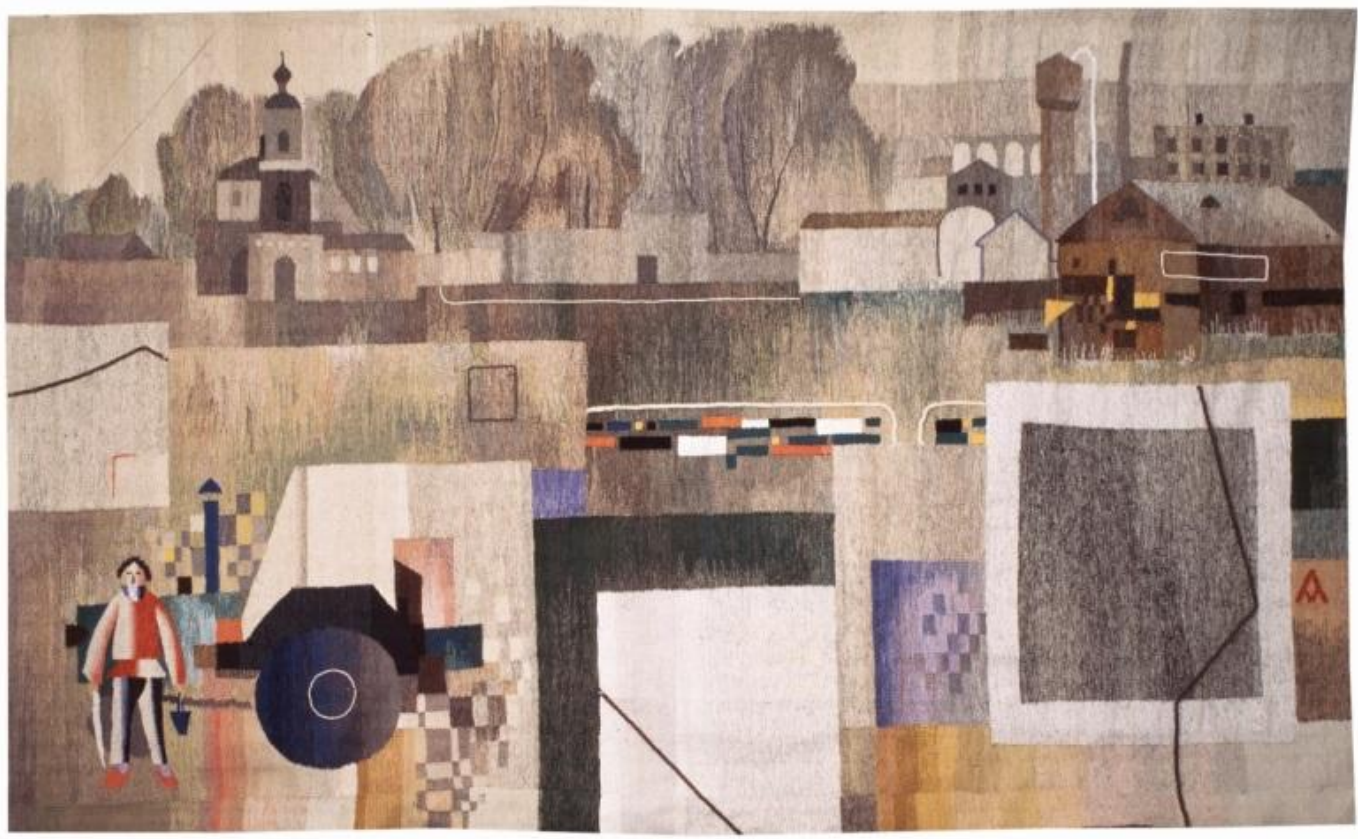

Görsel 22: “Süprematizm”, Andrey Madekin, 150x200cm, 1988. (Kaynak: Sanatçının kişisel arşivinden)

Andrey Madekin'in ilk tapestry uygulamaları "Süprematizm” (Görsel 22) ve "Bilinmeyen Kadın" (Görsel 23) adlı eserleridir. Sanatçı her iki eserini, 20. yüzyıl başlarının sanatsal geleneklerinin etkisi altında kalarak yaptığını belirtmiştir. Moskova Sanatçllar Birliği Koleksiyonunda bulunan "Süprematizm" adlı tapestry çalışmasını Rus ressam Kazimir Severinoviç Malevich (1879-1935) anısına adamıştır (Madekin, 2020b). Süprematizm, Malevich tarafından geliştirilmiş bir akımdır. Bu akımın sanatçıları eserlerinde, geometrik soyutlama ile tinsel gerçekliği anlatmaktadır (Little, 2008: 112). Madekin'in Malevich'e ithaf ettiği eseri, anlatım dili ve kompozisyon kurgusu bakımından akımın özelliklerini yansıtmaktadır. 


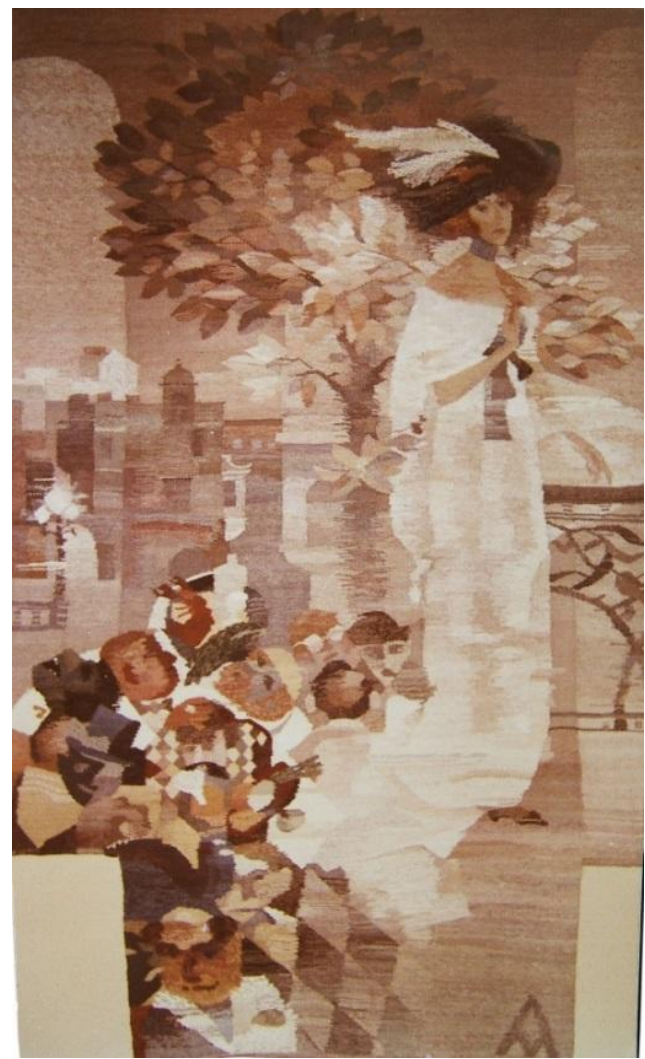

Görsel 23: “Bilinmeyen kadın”, Andrey Madekin, 250x50cm, 1987, Özel Koleksiyon, Fransa. (Kaynak: Sanatçının kişisel arşivinden)

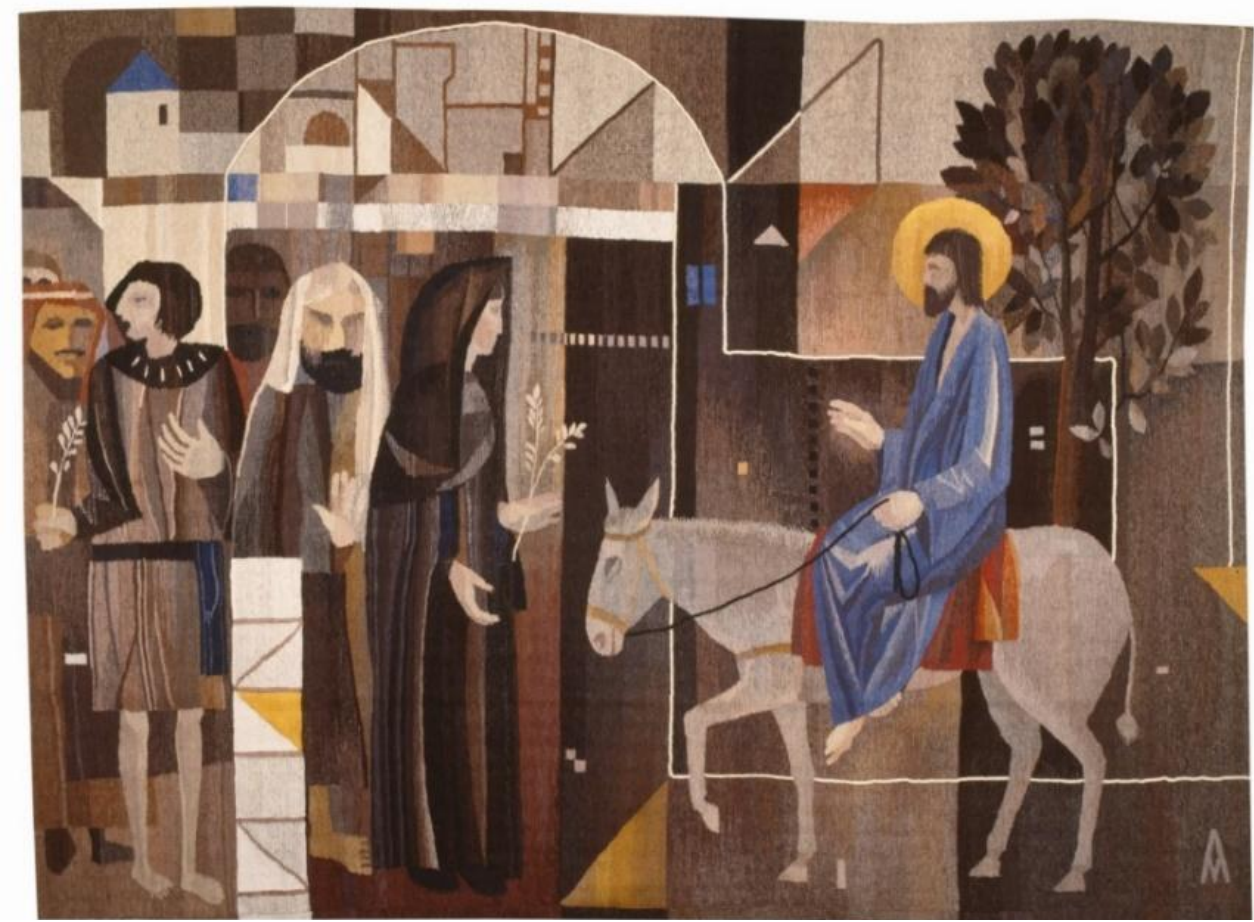

Görsel 24: "Kudüs'e Giriş”, Andrey Madekin, 200x250 cm, Rusya Kültür Bakanlığ1 Koleksiyonu, 1989. (Kaynak: Sanatçının kişisel arşivinden) 
Madekin sonraki çalışmalarında tarihi ve dini metinlerden aldığ tapestry dokumalarına uygulamıştır. 20. yüzyılın başlarında "Kudüs'e Giriş", "Cana of Galilee'de Dügün" ve "Son Akşam Yemeği" adlı eserleri ile İncil temalı bir üçleme yaratmıştır. Sanatçı bu eserlerde seçilen temaların sembolik olduğunu belirtmiştir. Cana'daki düğünde, Mesih'in ilk mucizeyi gerçekleştirmesi bir dizi başka mucizeleri başlatır; Kudüs'e giriş, Mesih'in Tanrıya adanan hizmetinin başlangıcıdır ve Son Akşam Yemeği, Aşai rabbai ayininin oluşma zamanıdır. Bu eserler Tsaritsyno Devlet Müzesi'nde ve Rusya Federasyonu Kültür Bakanlı̆̆ fonlarında yer almaktadır. Madekin bütün tapestry çalışmalarının kendisi için özel olduğunu, hepsini özenle dokuduğunu fakat dördüncü eseri olan “Kudüs'e Giriş” (Görsel 24) adlı çalışmasının ayrı bir yeri olduğunu ifade etmiştir. Sanatçı henüz 26 yaşındayken, bu eseri tasarlayıp dokuduktan sonra Rusya'da Devlet Sanatçılar Birliği'ne kabul edilmiştir (Madekin, 2020b).

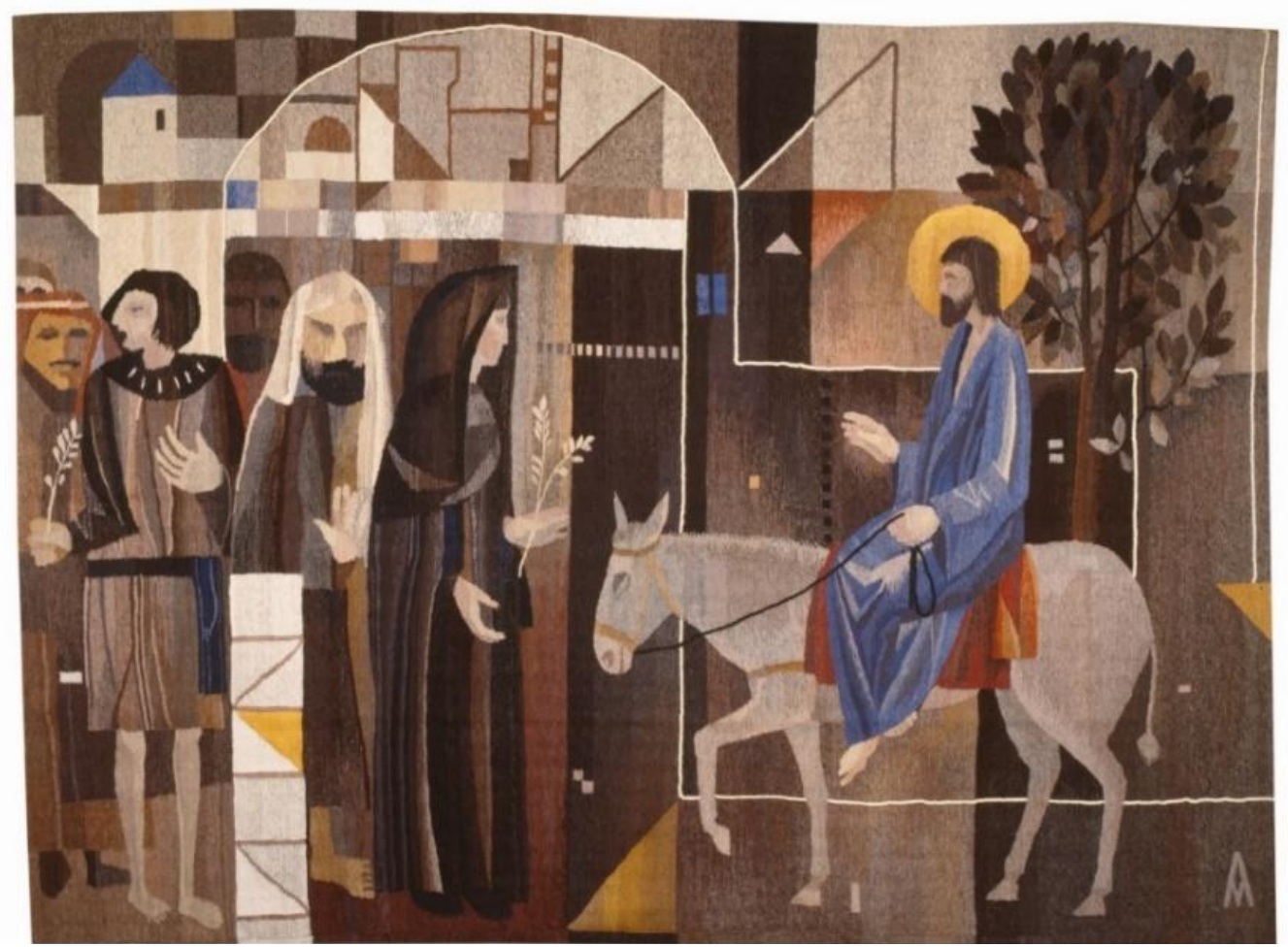

Görsel 24: "Kudüs'e Giriş", Andrey Madekin, 200x250 cm, Rusya Kültür Bakanlığ1 Koleksiyonu, 1989. (Kaynak: Sanatçının kişisel arşivinden)

Madekin "Yorgi" adlı eserinde, çoğu eserinde olduğu gibi önce yağlıboya ile eskiz çalışmasını yapmış, sonrasında $4 \mathrm{~m} 2$ 'lik tapestry dokumasını gerçekleştirmiştir. Mitolojiden esinlendiği bu çalışması 1993 yılında Belçika' da Doğu Avrupalı sanatçıların çalışmalarının sergilendiği büyük bir karma sergi etkinliğinde izleyiciye sunulmuştur. Bu eser, şu anda da Rusya'da İvanova müzesinde sergilenmektedir. 


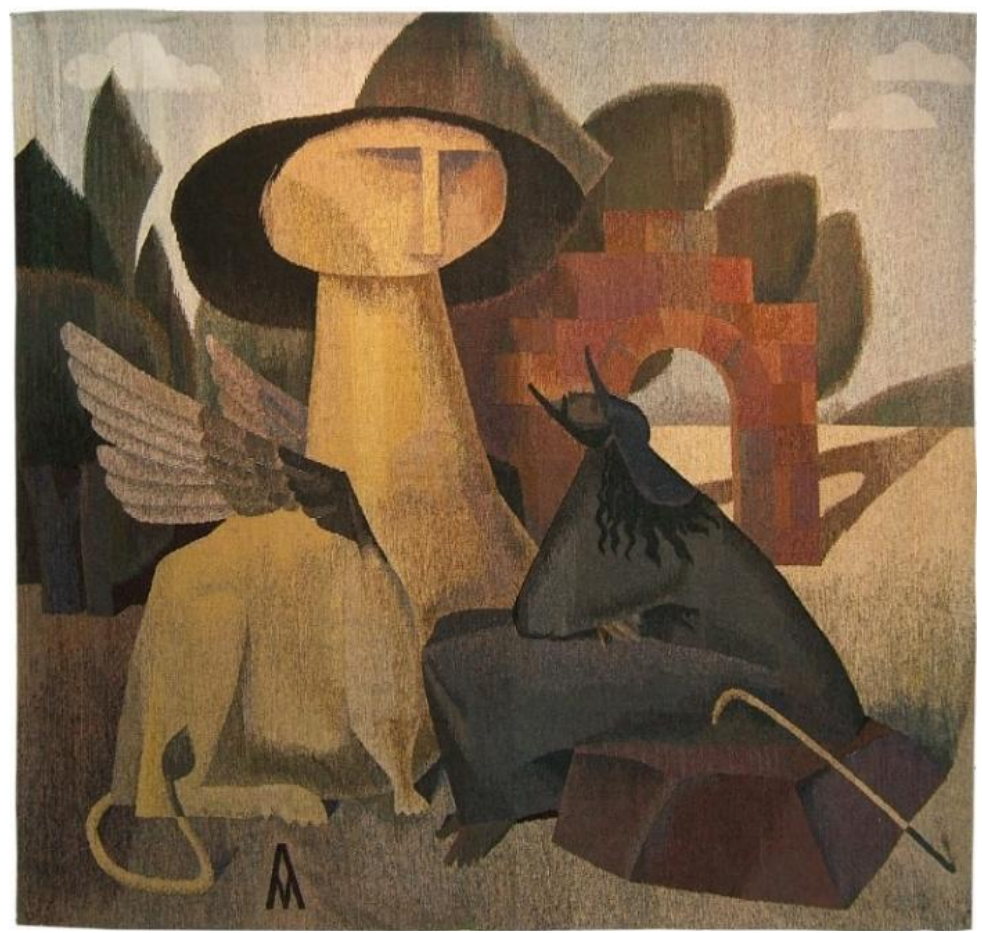

Görsel 25: "Yorgi", Andrey Madekin, 200x220cm, 1992. (Kaynak: Sanatçının kişisel arşivinden)

1990'l1 yılların ortalarında sanatçı, kendisine meydan okuyarak dekoratif stilden gerçekçi üsluba geçmiştir. Bu geçişin nedenleri arasında, içinde bulunulan ekonomik koşullardan dolayı resmi kurumların güçlü desteğinin kesilmesi ve bu kesintiden sonra kendi başına ayakta kalma çabasıdır. Özel tapestry sipariş veren kişilerin, daha sade, anlaşılabilir ve daha gerçekçi üslupla dokunmuş ürünleri talep ettiği ifade edilmektedir. Bu teknikte gerçekçi görüntü oluşturmak, stilize bir dekoratif çalışmadan çok daha zordur. Uygulamada en ufak bir hata hemen dikkat çekmektedir. Madekin, artık gerçekçilikten sıkıldığını ve daha çok dekoratif stile dönmek istediğini belirtmiştir. Sanatçı, müşterileri tarafından yönlendirilmek yerine, içgüdüleriyle sanat ürettiğinde, ancak o koşullarda, sıradan bir eşyanın bile sanat eserine dönüşebileceğini belirtmektedir (Dvorkina, 2010: 12-13).

Madekin, 1993 yılında İlahiyatçı L. Regelson'ın "Kıyametin Yorumlanması" adlı kitabı için 50'ye yakın resimli ve grafik illüstrasyon yapmıştır. Tapestry uygulamalarına göre resim yapmanın baştan çıkartıcı hızı Madekin'i duvar halılarından uzaklaştırmamıştır. Sanatçı bunun nedenini, tapestrylerin dokusunun benzersiz estetik özelliklerine ve tapestry sanatının, ev şartlarında anıtsal sanat eseri oluşturulmasına imkân veren belki de tek sanat dalı olmasına bağlamaktadır (Dvorkina, 2010: 11).

Theophanes the Greek'in ilham verici fresklerinden Giorgio de Chirico'nun metafizik resmine kadar çeşitli ustaların etkisi altında sanatçı kimliği gelişen 
Madekin'in, kendine özgü tarzı açıkça ortaya çıkmaktadır. "Müneccimler Yolu”, "Mısır'a Kaçış", "St. Andrey Haberi”, "Seraphim Sarovskiy" gibi eserlerinde de görüldüğü üzere, bu temanın diğer çalışmalarında da devam ettiği gözlemlenmektedir. Madekin "Oidipus ve Sfenks", "Hermes", “Europa'nın Kaçırılışı" ve "Pegasus'un Uçuşu" gibi eserleri ile etkilendiği mitolojik temaları tapestry dokumalarında konu olarak ele almıştır. Sanatçı, insanlığı ilgilendiren felsefi sorunların, eserleri ile metaforik bir ifade bulduğu görüşünü vurgulamıştır (Madekin, 2020b).

Madekin özel bir koleksiyonda yer alan "Europa'nın Kaçırılışı " (Görsel 26) adlı eserinde, Yunan mitolojisinde bulunan, Zeus'un boğa kılığına girerek Europa adındaki Fenikeli prensesi kaçırma sahnesini konu almıştır. Sanatçının bu eserinde mekân ve figürlerde geometrik formlar gözlemlenirken, 2016 yılında dokuduğu aynı isimli tapestry dokumasında (Görsel 27) figürlerin daha kıvrımlı hatlarla oluşturulduğu, mekânda detay anlatımların olduğu, daha canlı renklerde ipliklerle uygulandığ1 görülmektedir. Madekin'in özel bir koleksiyonda yer alan “Leda ve Kuğu" adlı diğer bir çalışmasında, kuğunun zarifliği, doğanın ve figürün gerçekçi gözle dokunarak, detaylı olarak resmedilmesi oldukça etkileyicidir.

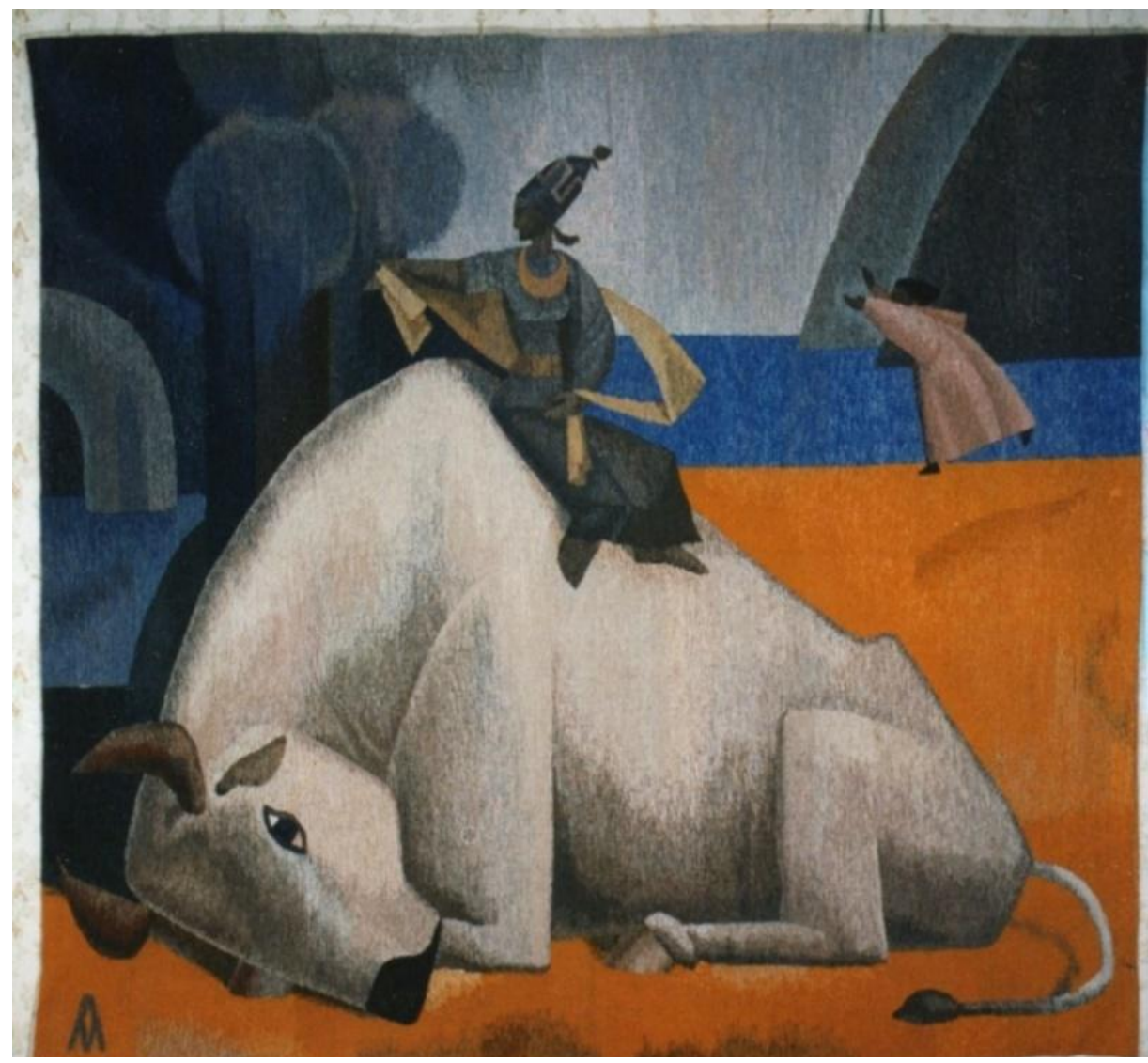

Görsel 26: "Europa'nın Kaçırılışı ", Andrey Madekin, 200x220cm, 1993. (Kaynak: Sanatçının kişisel arşivinden) 

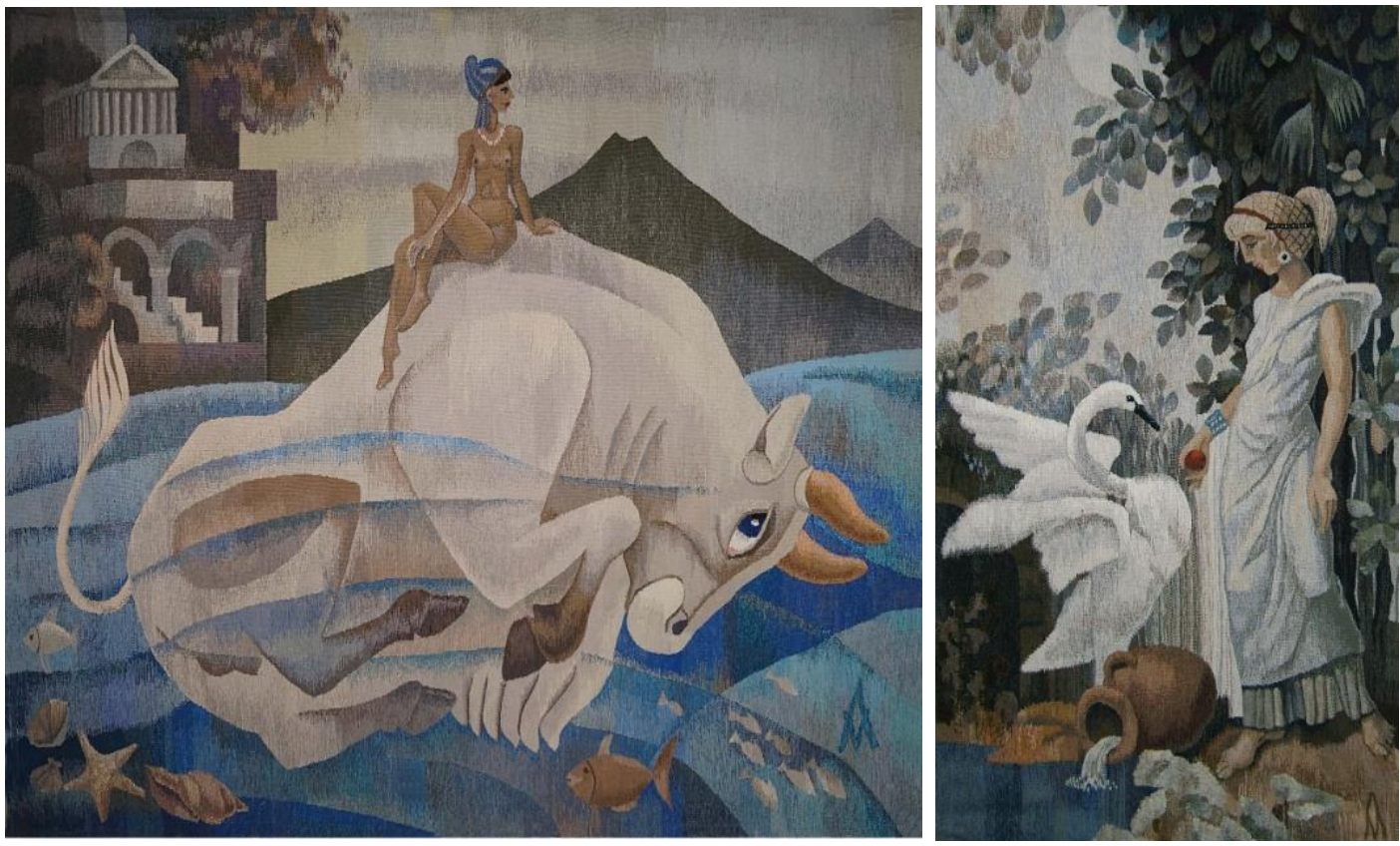

Görsel 27: “Europa'nın Kaçırılışı”, Andrey Madekin, 200x215cm, 2016. (Kaynak: Sanatçının kişisel arşivinden)

Görsel 28: "Leda ve Kuğu”, Andrey Madekin, 200x110cm, Özel Koleksiyon 2002. (Kaynak: Sanatçının kişisel arşivinden)

“Son Akşam Yemeği” (1990), “Bathsheba” (1991), “Oidipus ve Sfenks” (1992), "Europa'nın Kaçırılışı" (1993) gibi eserlerinde dini veya mitolojik konuları temel alan ustalaşmış kanonik uslubunu geride bırakarak, bazen güçlü bir grotesk yapıyla sonuçlanan kendi çözümünü bulmuştur. Son zamanlarda dokuduğu önemli eserleri arasında "Magi' nin Yolu" (2009), "Şeytanları Kovmak " (2012), "Süleyman ve Sheba Kraliçesi" (2014), "Fırtınayı Sakinleştirmek" (2016), “Europa'nın Kaçırılması" (2016) gibi eserler bulunmaktadır ve Madekin'in sanatsal üslubuna ait el izi her zaman kendini fark ettirmektedir (Dvorkina, 2018: 197).

Madekin özel bir koleksiyonda bulunan "Pegasus'un Uçuşu” (Görsel 29) adlı eserinde, Yunan mitolojisinde bulunan kanatlı at Pegasus'u konu almıştır. Sanatçı bu çalışması ile ilgili ilginç bir hikâyesi olduğunu vurgulamıştır. Tapestry çalışmasını tamamladıktan sonra beklenmedik bir şekilde Türk halı imalatçılarıyla ticari ilişkiler kurmak için Antalya'ya davet edilmiştir (Madekin, 2020b). Antik mitolojiye göre kanatlı at Pegasus, Türkiye'de Kemer bölgesinde, Antalya'ya çok uzak olmayan Olimpos Dağı'nda yaşamıştır. Sanatçı 2006 yılında Antalya Kemer'e geldiğinde, bölgedeki dağları da gezmiş ve manzaraları fotoğraflarla belgelemiştir. Sonrasında yaptığı bir resimde bu manzara ile Pegasus'u bir tabloda buluşturmuştur. İki kez İstanbul'da bulunduğunu söyleyen Madekin, eski İstanbul'u, Ayasofya'yı, Kariye'yi tek başına adım adım gezdiğinden söz etmiştir. İstanbul'dan etkilenen sanatçı, bu manzaraları konu alan resimler yapmıştır (Madekin, 2020a). 


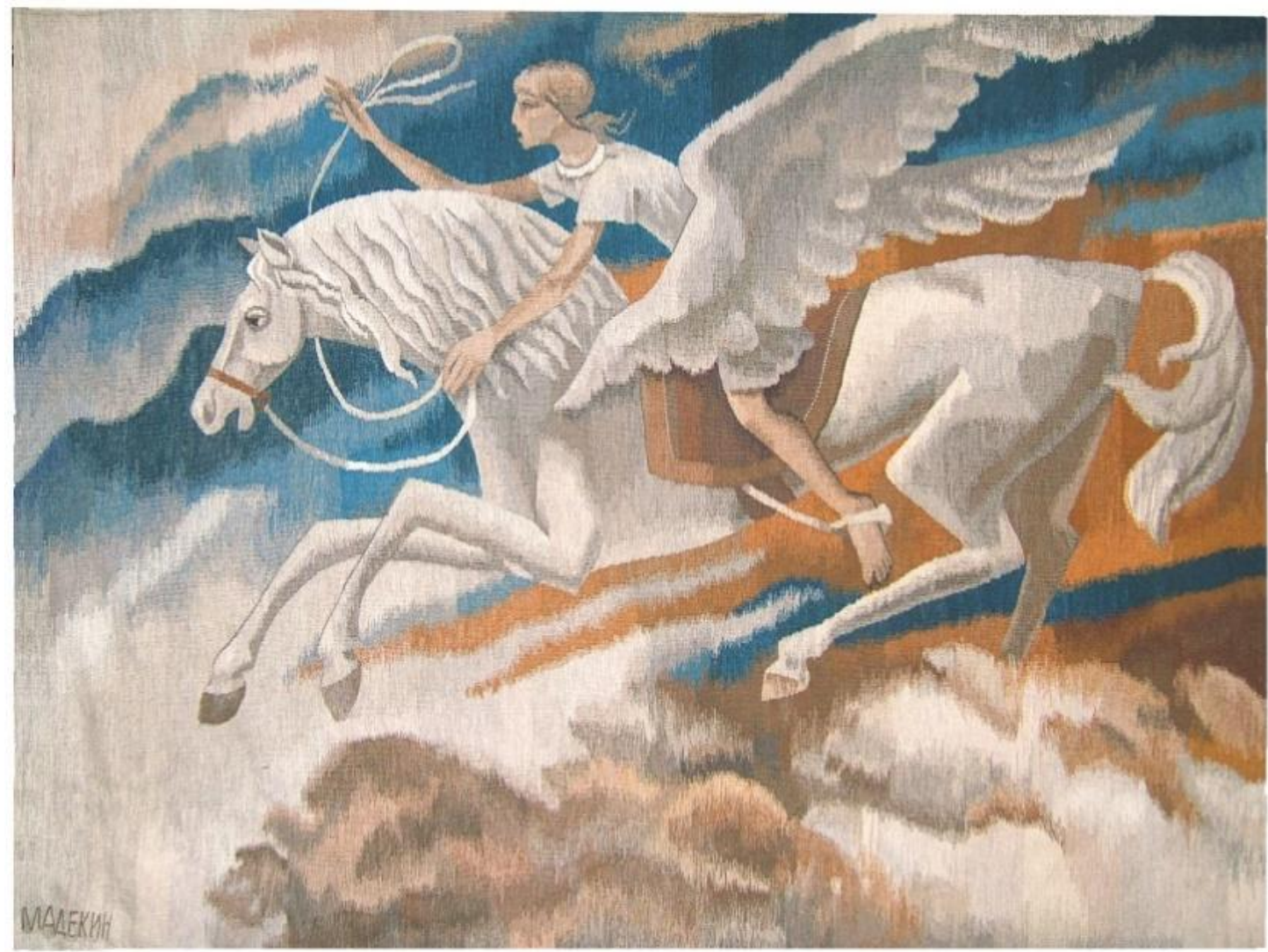

Görsel 29: "Pegasus Uçuşu”, Andrey Madekin, 150x200cm, Özel Koleksiyon, Moskova, 2006. (Kaynak: Sanatçının kişisel arşivinden)
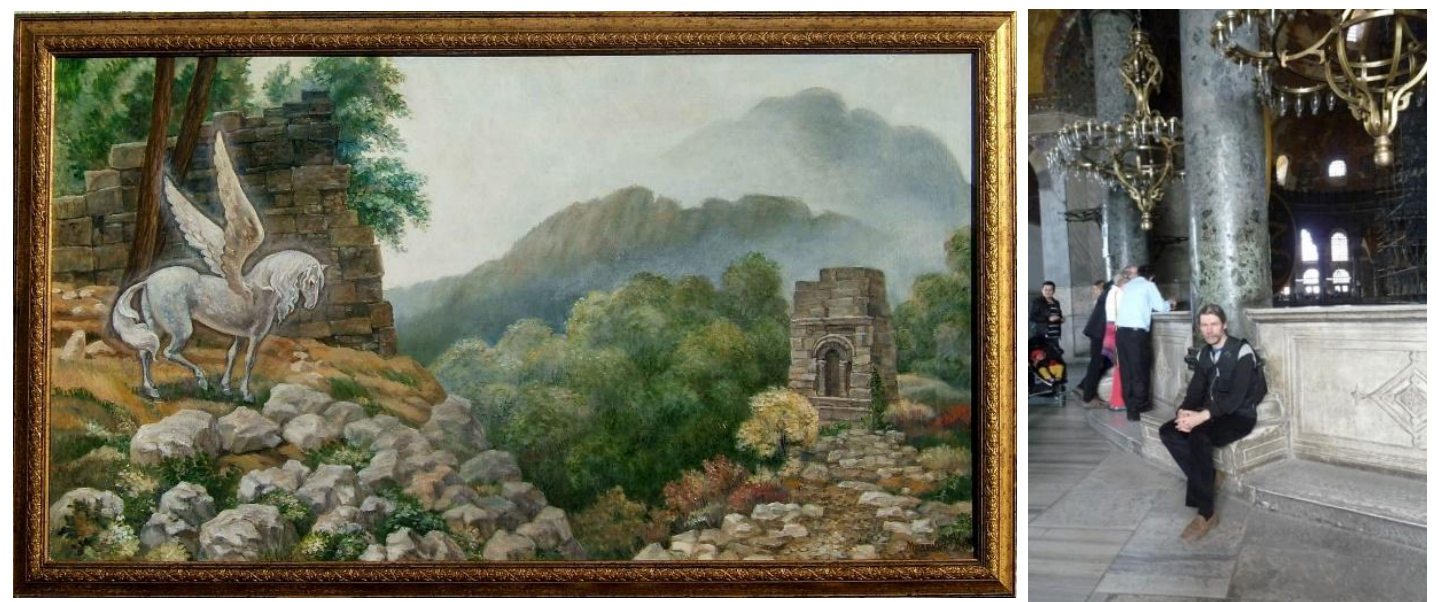

Görsel 30: "Pegasus", Andrey Madekin, tuval üzerine yağlıboya, 60x110 cm, 2007. Antalya'da bulunan Termesos antik kentinin görünümü peyzaj olarak kullanılmıştır. (Kaynak: Sanatçının kişisel arşivinden)

Görsel 31: Andrey Madekin, Ayasofya, 2014. (Kaynak: Sanatçının kişisel arşivinden) 

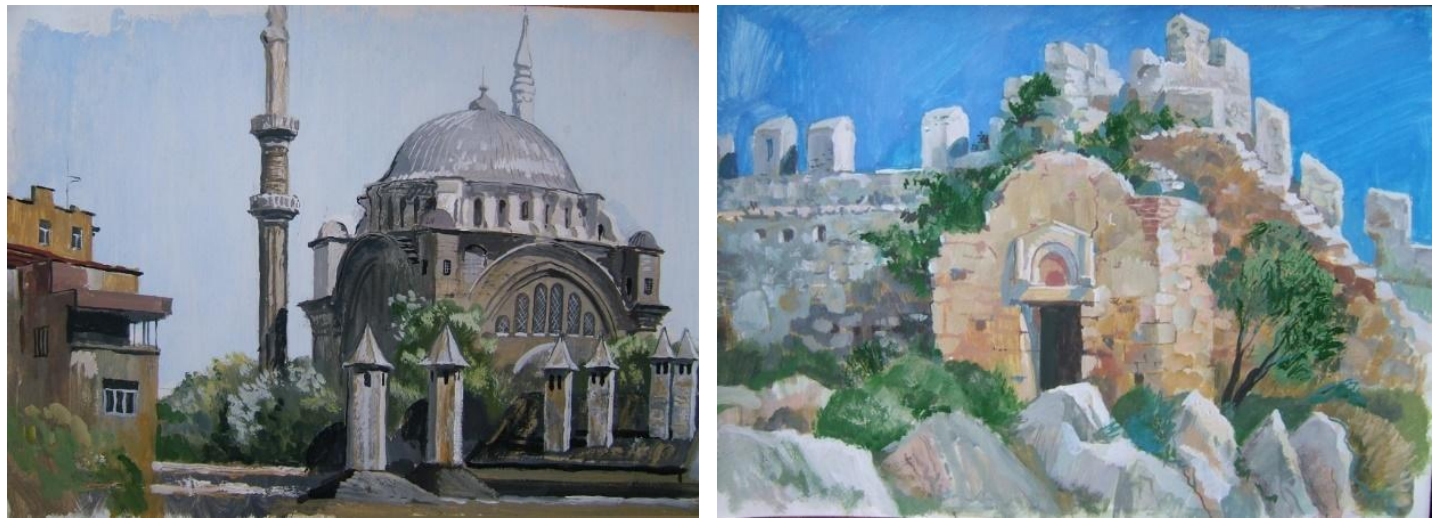

Görsel 32: Beyazıt Cami, İstanbul, kâğıt üzerine guaj boya, 30x40cm, 2002. (Kaynak: Sanatçının kişisel arşivinden)

Görsel 33: Alanya Şehrinde Bir Kale Yıkıntısı Üzerine Çalışma, kâğıt üzerine guaj boya, 30x40cm, 2000. (Kaynak: Sanatçının kişisel arşivinden)

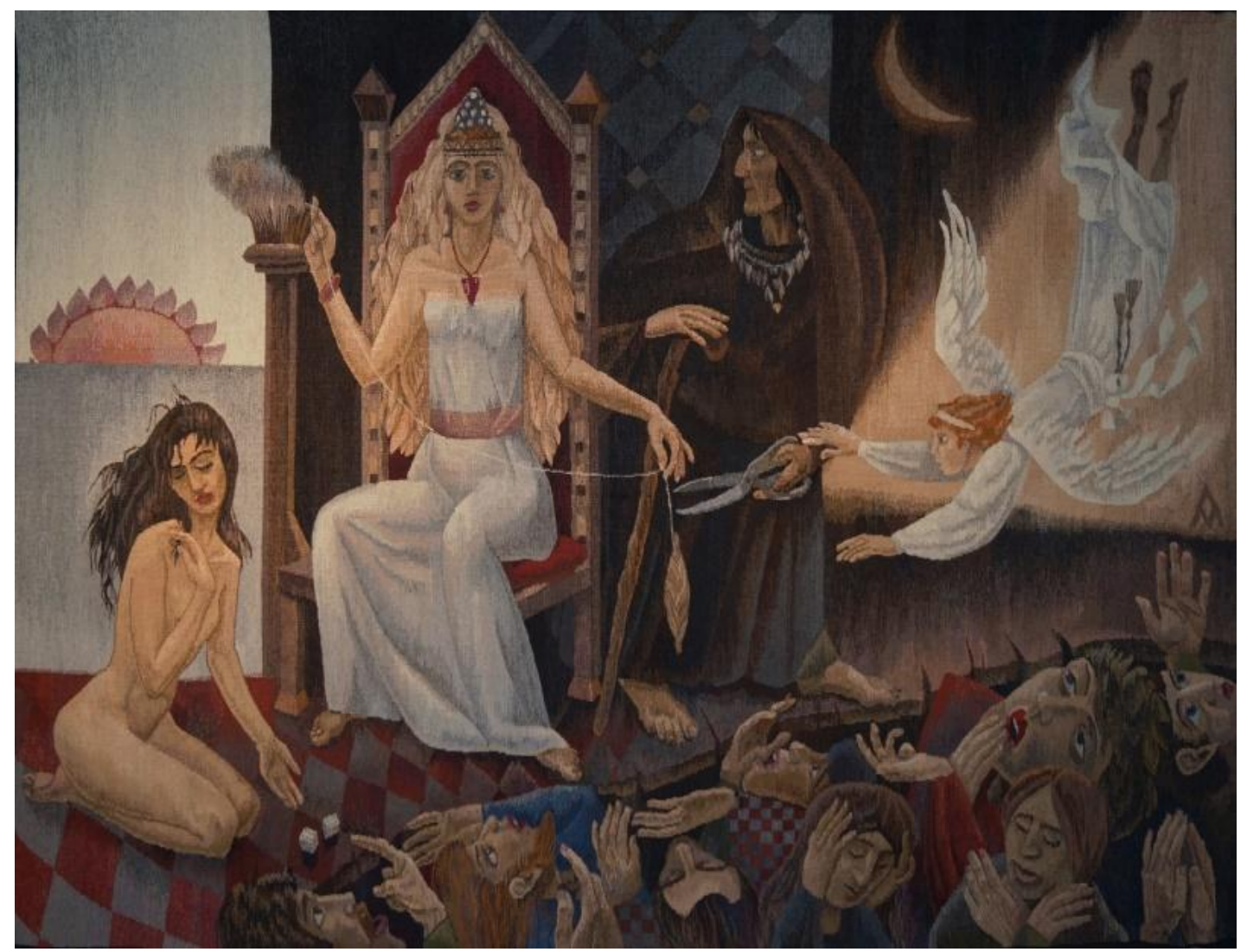

Görsel 34: "Moira Tanrıçaları", Andrey Madekin, 200x255cm, 2018. (Kaynak: Sanatçının kişisel arşivinden) 
Yunan mitolojisinde yer alan Moira, ecel ve kader tanrıçası olan üç kız kardeşe verilen isimdir. İnsanların kaderini belirlediklerine inanılmaktadır. Madekin tapestry çalışmasında (Görsel 34) konu aldığı mitolojik hikâyede, en küçük kardeşin ipliği oluşturduğunu, ikincisinin ipliğin uzunluğunu belirlediğini ve üçüncü kardeşin ise kişinin ölümü anında ipliği kestiğini belirtmiştir. Ancak Tykhe talih tanrıçası bu duruma müdahale edebilmektedir. Sanatçı tapestry uygulamasında Tykhe'yi, son anda kaderin hükmünü değiştirebilecek bir melek şeklinde tasvir etmiştir (Madekin, 2020b). Sanatçının "Şeytanları Kovmak" adlı tapestry dokumasına bakıldığında (Görsel 35), canlıların betimlenmesinde, her birinin farklı karaktere sahip olduğu gözlemlenmekte, aynı zamanda yüzlerin de en az insanlar kadar anlam taşıdığı görülmektedir (Dvorkina, 2018: 197).

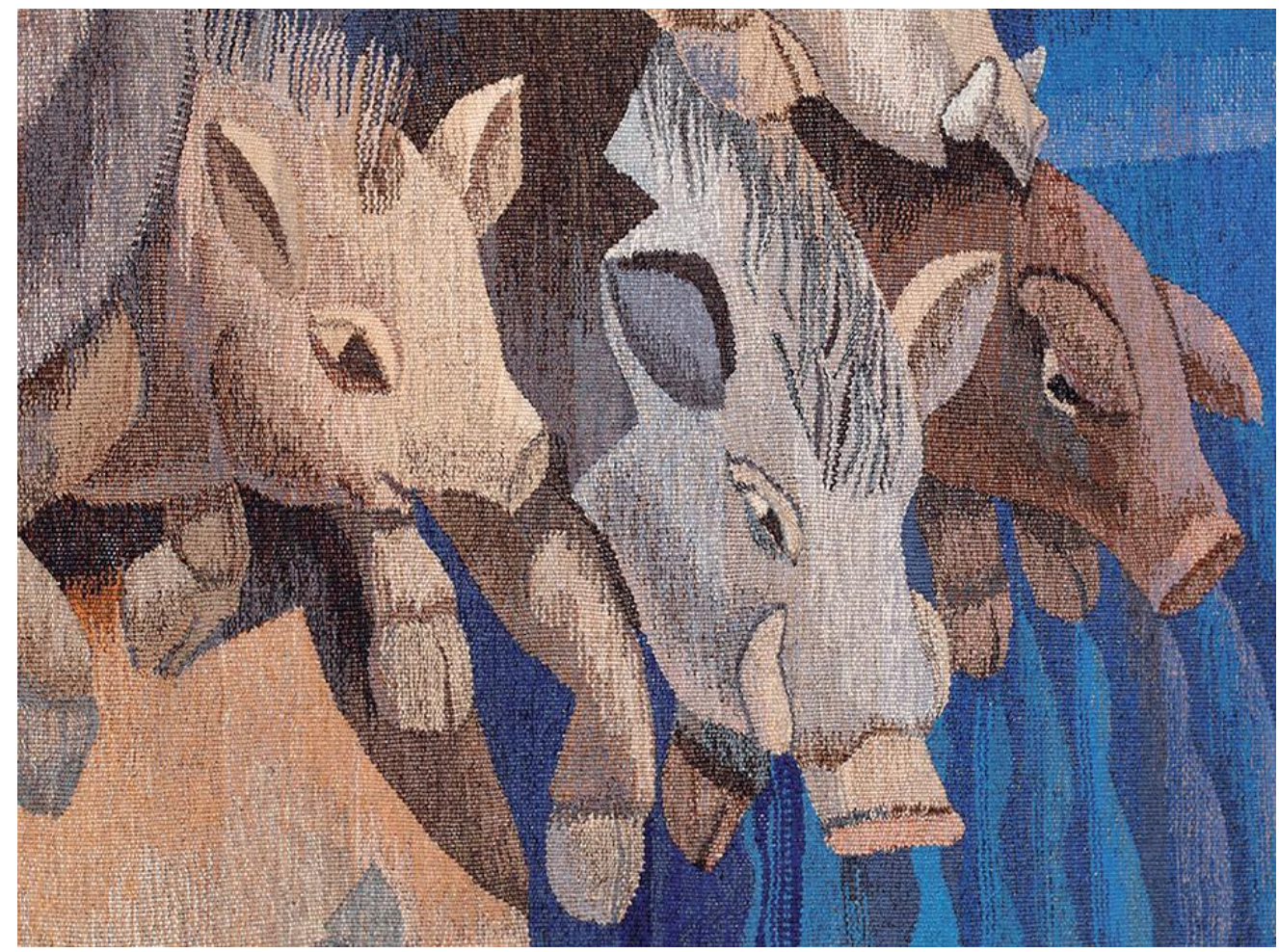

Görsel 35: "Şeytanları Kovmak", Andrey Madekin, 200x250cm, 2012. (Kaynak: Dvorkina, 2018: 198)

Madekin eserlerini tasarlayıp, uygularken tapestry dokumalarına başlamadan önce, eskizlerin yanı sıra guaj ya da yağlı boya ile ilk olarak tablolarını yapmaktadır. Kompozisyonu uygulama yapacağı boyutta kâğıda, kalemle ana hatlarını çizerek aktarmakta ve sonrasında dokuma işlemini uygulamaya başlamaktadır (Madekin, 2020a). Klasik tapestry uygulamalarında olduğu gibi eskiz kâğıdını çözgü ipliklerinin arkasına yerleştirerek, renk alanlarına uygun iplikler kullanarak resimsel nitelikler taşıyan dokumalarını gerçekleştirmektedir. Görsel 36'da görüldüğü gibi sanatçı büyük boyutlu uygulamalarında tezgâhta, tapestrylerin yönünü yatay olarak planlayıp, dokumasını gerçekleştirmektedir. 


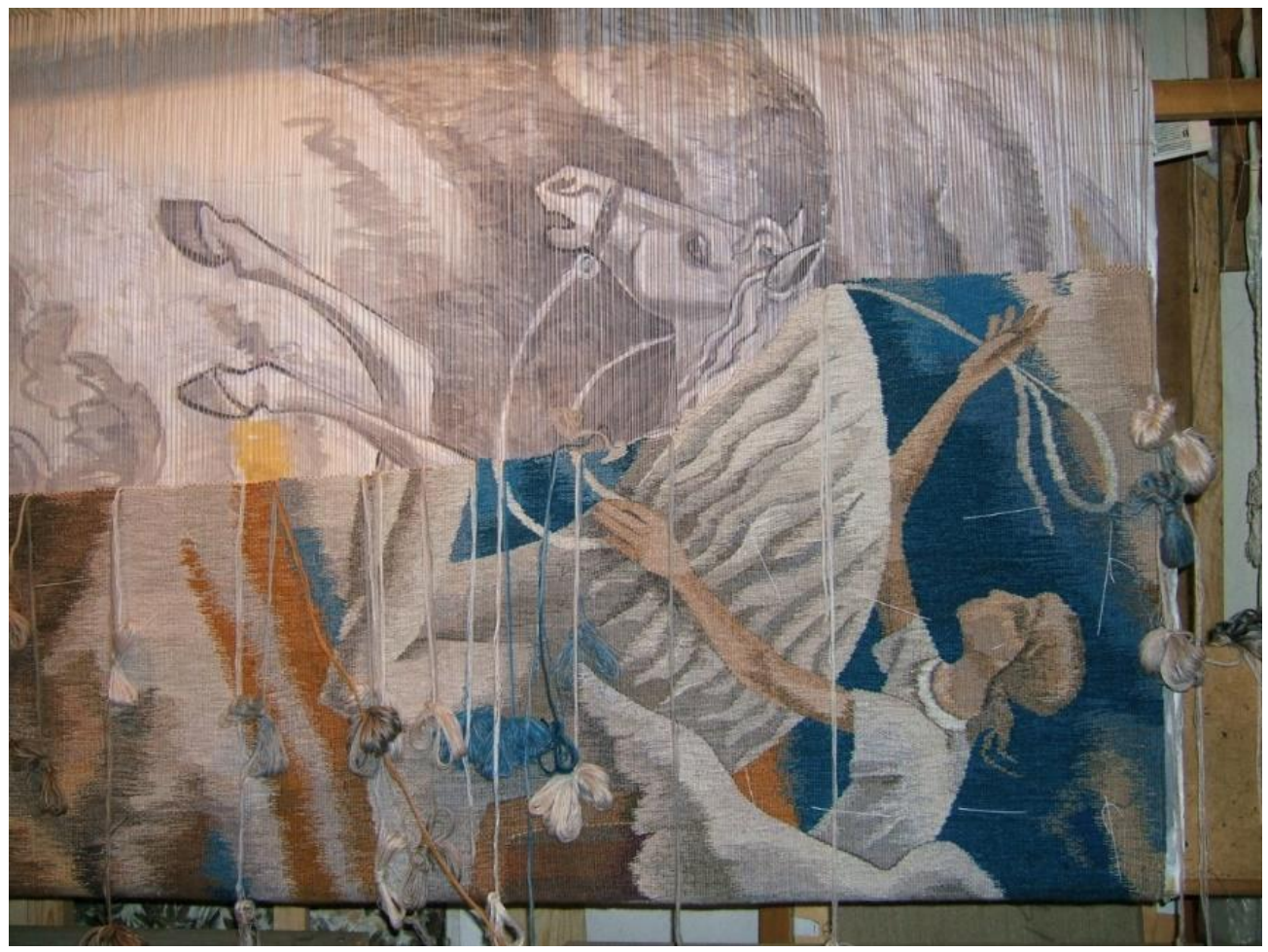

Görsel 36: "Pegasus Uçuşu" adlı eserin dokunduğu tezgâhta uygulama aşaması. (Kaynak: Sanatçının kişisel arşivinden)

Sanatçı malzeme olarak hazır boya kullanılarak elde edilen renkli iplikler kullandığını ifade etmiştir. Farklı renk ve tonlarda iplikleri birleştirerek melanj iplik elde etmekte ve bu sayede dokumada daha detaylı resimleme çalışmaları yapabilmektedir. Daha önce klasik çalışmalar gerçekleştirdiğini, şu anda yaptığı tapestrylerin kendi iç dünyasıly ilgili eserler olduğunu belirtmiştir (Madekin, 2020a).

Madekin eserlerinde mozaik sanatını anımsatan bir üslup kullanmaktadır, ancak malzemenin ortama katılması ile eserlerde esneklik ve aynı zamanda özel bir yumuşaklık ortaya çıkmaktadır. Resimsel ön örneklerde yer alan renk alanlarındaki farklılıklar; boyamada karışım alanlar kurgulanarak ve bir dizi ara ton oluşturularak sağlanmıştır. Sanatçı; dokuma yüzeyini, ipliğin renklerini ve özelliklerini ustaca bağdaştırarak, yalnızca gözün belirli bir mesafeden algıladığ1 ayrı renk noktalarının birbirini tamamlaması ile oluşturmaktadır. Madekin'in eserlerine; yakından bakıldığında tek tek noktaların algılandığı, belli bir mesafeden bakıldığında bu noktaların bütün algısını oluşturduğu görülmektedir. Eserin görüntüsünde tamamlayıcı bir rol oynayan, birleştirici bir yöntemle çalışmaktadır.

Sanatçının duvar halıları, etkileyici ayrıntıların dengesi ve bir bütün olarak kompozisyonun genelleştirilmesiyle karakterize edilmiştir. Madekin'in, karakterlerin tipik ulusal ve bireysel özelliklerini dokuma yoluyla aktarabilme yeteneği etkileyicidir. Anlatım diline bağlı olarak sanatçının dekoratif duvar halıları 
her zaman derin içerik ve sembolizmle doludur. İlişkilendirme, felsefi temalar, mitoloji ve olay örgüsünü kendi tarzlarında görme ve sunma yeteneği, Madekin ve çalışmalarını zamanın önemli, ayırt edilir bir fenomeni haline getirmektedir (Dvorkina, 2018: 198).

Madekin günümüzde de tapestry uygulamalarını farklı yaklaşımlarla gerçekleştirmektedir. İlgi çekebilecek temaları ve gündemde olan konuları seçerek resimlediği ve uyguladığı dokumalar bulunmaktadır (Madekin, 2020a). Eserlerinin yaklaşık yarısı, kendi yaratıcı konseptine uygun seçilmiş, sergiler için yaptığı çalışmalardır. Felsefi düşüncelerini tarih ve din temaları üzerinden ifade etmeye ve yansıtmaya çalışmaktadır. Kamusal ve seçilmiş özel iç mekânlar için duvar halıları tasarlamakta ve uygulamaktadır. Bu tür çalışmalarda mimari ortamın özelliklerini ve müşterilerin isteklerini dikkate aldığını ve değerlendirdiğini belirtmektedir (Madekin, 2020b). Özgün tapestry uygulamalarını, Picasso ve Braque gibi Kübist sanatçılardan ve Sürrealist ressam Giorgio de Chirico'dan ilham alarak uyguladığı eserler olarak iki tema ile ilişkilendirebiliriz. Madekin bu çalışmalarını İncil tasvirleriyle birleştirerek mimari ile bütünleştirmektedir (Russell, 2019: 23).

Sanatçı iç mekân çalışmalarında yapılan eserin insanların hayatında uzun yıllar bulunabileceğini ve duvarda asılı kalabileceğini belirtmektedir. Bu nedenle olay örgüsünün ve çalışmanın genel etkisinin pozitif bir enerjiye sahip olması ve gözleri rahatsız etmemesi gerektiğini ifade etmiş, "insan ruhuna olumsuz etki ile dokunulmamasının önemini" vurgulamıştır. Ayrıca eserin çevreyle uyum içinde, doğru ölçülerde olması, sergilendiği alanın merkezi haline gelmesi ve bakanı etkilemesi gerektiği üzerinde durmaktadır (Dvorkina, 2018: 197).

\section{Sonuç}

Eski ve köklü bir geçmişi olan Rus tekstilleri içinde özel bir yere sahip, duvar askısı adını da alan, sanatsal üretim kapsamındaki tapestry dokumalar Rusya'da halen üretilmektedir. Bu alanda çalışan sanatçılar tarafından üretilen, klasik üslupla ve malzemelerle dokunan tapestry örnekleri bulunmaktadır. Aynı zamanda deneysel çalışmaların ürünü olan yenilikçi yöntemler ve malzemelerin kullanıldığ duvar askıları da Rusya'yı temsil eden sanatsal çalışmalar olarak uluslararası etkinliklerde yer almaktadır.

$\mathrm{Bu}$ araştırma; üreten ve uluslararası tanınırlığı olan Madekin'i ve eserlerini Türkiye'de tanıtmak için yapılan bir çalışmadır. Sanatçı ile gerçekleştirilen sözlü ve yazılı iletişimin yanı sıra, Rusça, İngilizce ve Türkçe kaynaklardan yararlanılmıştır.

Kendine özgü üslubunu oluşturan Madekin, büyük boyutlu eserler uygularken, yoğun vakit alan klasik tapestry tekniğini kullanmaktadır. Tapestry dokumalarında sipariş alarak ya da sergi amaçlı özgün uygulamalarla dokumalarını gerçekleştirmektedir. Geleneğin izlerini taşıyan klasik ya da Rus sanat unsurlarını barındıran, çok yönlü yaklaşımlar sergileyen, modern ve özgün eserleriyle 
uluslararası sanatçılar arasında özel bir yere sahiptir. Sanatçı, tapestry dokumaları ile ismini duyurmuş, birçok müze, özel koleksiyon, çeşitli sergi ve etkinliklerde eserleri ile kendini ve Rusya'yı temsil etmiştir.

Tasarımc1, ressam ve yazar kimlikleri olan sanatçının eğitimci yönü de bulunmaktadır. Madekin'in farklı disiplinlerde üretken olması tapestry dokumalarındaki başarısını etkilemiş, birçok ülkede sanatçı kimliği ile tanınmasına olanak vermiştir. Edebi yönü konuyu seçimini ve yorumlamasını desteklemiş, ressam kimliği renk ve biçim unsurlarını profesyonelce kullanmasına yön vermiştir. Aile geçmişinden gelen tekstil kodları malzeme ve yöntemle diyalog kurmasına kolaylık sağlamıştır.

Madekin'in yaptığı çalışmalara bakıldığında, konuyu uygulamalarına aktarırken figürlerin karakterlerini detaylı olarak yansıttığı görülmektedir. $\mathrm{Bu}$ konudaki başarısı; malzeme, renk ve biçim gibi unsurların birlikteliğinden doğan uyuma bağlanabilir. Buna ek olarak, sanatsal dürtülerini incelikle kullanabilmekte ve yaptığı eserlerde kimliğini hissettirmektedir.

Sonuç olarak; Andey (Andrew) Madekin, resim sanatının tekstil bağlamında önemli bir parçası olan tapestry eserlerinde; düzen, kompozisyon, renk, biçim ve konu özgünlüğü itibari ile farklı bir üslup oluşturarak, uluslararası düzeyde ün kazanmayı başarmıştır.

\section{KAYNAKÇA}

Cooper, A. (1992). Luxury Textiles From Feudal Workshops: 19th Century Russian TapestryWoven Shawls. Textile Society of America Symposium Proceedings. 564. Page: 225-236.

Dvorkina, I. (2018). HAND WEAVING. History. Modernity. Weaving. (Tapestry, Carpets). Volumes 1-6. Moscow, 2018. Out of print v. 1-3. Prepares for printing v. 4-6. volume. 3. chapter «Tapestry in the post-Soviet territory». P. 195-217.

Dvorkina, İ. (2010). Tkanye Freski: Evangeli ot Andreya. Deko 3, 10-13. Issn: 1816-0190.

Fitz- Gibbon, K. (2004). Something Borrowed, Something Red -Textiles in Colonial and Soviet Central A. Textile Society of America 9th Biennial Symposium. Page. 123-133.

Gazizova, A. T. (2015). İstoriya Razvitiya Ruçnogo Tkaçestva Ot Gobelena Do Tapiseriy. İzestiya Samarskogo nauçnogo tsentra Rossiyskoy akademii nauk. 17, №1(4), 989-991.

Kochkurkina, S. \& Orfinskaya, O. (2016). Archaeological Textiles of the 10th to the 12th Century from the Gaigovo Barrow Group (Russia, Leningrad Oblast). Archaeological Textiles Review. No. 58. Page. 21-33.

Little, S. (2008). İzimler, Sanatı Anlamak. Yem Yayınları. 2. Baskı.

Lodder, C. (2018). Textiles for Revolutionary Russia: Training Textile Designers at the Moscow VKhUTEMAS. West 86th: A Journal of Decorative Arts, Design History, and Material Culture. Volume: 25. Number: 2. Page. 139-159. 
Meller, S. (2007). Russian Textiles: Printed Cloth for the Bazaars of Central Asia. New York: Harry N. Abrams.

Russell, K. (2019). Third Russian Triennial of Contemporary Tapestry 2017. Tapestry Weaver The British Tapestry Group. Issue 25 March 2019.

Wetenhall, T. (2010). Woven Blooms of Nationalism: Russian Handwoven TapestryTechnique Shawls. 1825-1855. Textile Society of America Symposium Proceedings. 58. Page: 1-6.

Yıldırım, L. Sakalauskaite, J. (2011). Devrim Sonrası "İlk Sovyet Modası'nın" Oluşturulmasına Popova ve Stepanova'nın Konstrüktivist Yaklaşımlarının Etkisi". Yedi, DEÜ GSF Dergisi. Sayı 6, Sayfa 31 - 39.

Korshunova, T.T. Hermitage Museum. Erişim Adresi: https://www.hermitagemuseum.org/wps/portal/hermitage/explore/collections/m aster/sub/1254020824/?lng=tr, Erişim Tarihi: 08.09.2020.

Madekin, Andrey (2020a). Çevrimiçi Ortamda Röportaj, 5 Kasım 2020.

Madekin, Andrey (2020b). Sanatçı ile kişisel e-posta yazışmaları, 7 Kasım 2020. 